\title{
AVALIAÇÃO DAS CONDIÇÕES MICROBIOLÓGICAS DE CARNES DE ANIMAIS SILVESTRES NO MUNICÍPIO DE SÃO PAULO
}

\author{
FLÁVIA SARKIS
}

Dissertação apresentada à Escola Superior de Agricultura "Luiz de Queiroz", Universidade de São Paulo, para obtenção do título de Mestre em Ciências, Área de Concentração: Ciência e Tecnologia de Alimentos.

PIRACICABA

Estado de São Paulo - Brasil

Julho -2002 


\title{
AVALIAÇÃO DAS CONDIÇÕES MICROBIOLÓGICAS DE CARNES DE ANIMAIS SILVESTRES NO MUNICÍPIO DE SÃO PAULO
}

\author{
FLÁVIA SARKIS
}

Engenheiro Agrônomo

Orientador: Prof. Dr. CLÁUDIO ROSA GALLO

Dissertação apresentada à Escola Superior de

Agricultura "Luiz de Queiroz", Universidade de São Paulo, para obtenção do título de Mestre em Ciências, Área de Concentração: Ciência e Tecnologia de Alimentos.

PIRACICABA

Estado de São Paulo - Brasil

Julho -2002 
Dados Internacionais de Catalogação na Publicação (CIP) DIVISÃO DE BIBLIOTECA E DOCUMENTAÇÃO - ESALQ/USP

\author{
Sarkis, Flávia \\ Avaliação das condições microbiológicas de carnes de animais silvestres no \\ município de São Paulo / Flávia Sarkis. - - Piracicaba, 2002. \\ 70 p. : il. \\ Dissertação (mestrado) - - Escola Superior de Agricultura Luiz de Queiroz, \\ 2002. \\ Bibliografia. \\ 1. Alimentos de origem animal 2. Animais silvestres 3. Caititus 4. Capivaras 5. \\ Carne 6. Javali 7. Microbiologia de alimentos I. Título
}

CDD 664.9

"Permitida a cópia total ou parcial deste documento, desde que citada a fonte - O autor" 
Aos meus amados pais Léo e Marcos,

Que tornaram esse sonho possível através do constante incentivo e amor a mim dedicados.

A minha irmã Fabianna,

Pela amizade incondicional, apoio e amor.

À minha querida filha Zazá, que me dá forças,

Por fazer minha vida mais doce e feliz. 


\section{AGRADECIMENTOS}

Ao Prof. Dr. Cláudio Rosa Gallo, pelos valiosos ensinamentos, pelo apoio, confiança e dedicação que tornaram possível a realização deste trabalho.

Às Professoras Marília Oetterer, Marina Vieira da Silva e Marta Helena F. Spoto, por toda atenção dispensada a este trabalho e pelas preciosas sugestões.

À Professora Sônia Maria de Stefano Piedade pela paciência, dedicação e pelos ensinamentos na área de estatística.

À Rose Ocangne, Denise A. L. Baptista e Cecília Nogueira, técnicas do laboratório de Microbiologia de Alimentos, pela amizade e auxílio fundamental na execução deste trabalho.

À Beatriz Giongo e Midiam Gustinelli pela dedicação e ajuda na biblioteca.

À secretária da Pós Graduação Regina Lourenço por todo apoio prestado.

Às amigas Romilda Germano e Fabiana Martini, pela longas tardes de estudo e pelas boas risadas.

À grande amiga Giovana Vergínia Barancelli, pela dedicação incondicional durante todo o período experimental, pelo incentivo nos momentos difíceis e pela disposição em ajudar.

Ao amigo Antonio Bianchi pelo apoio prestado, dicas e conselhos.

À bibliotecária Ligiana Clemente pelo carinho com que fez as correções das referências bibliográficas.

À CAPES pela concessão da bolsa de estudo. 
Ao meu cunhado Alexandre pela amizade, carinho e principalmente pelos passeios com a Zazá.

À minha querida avó Josepha pelo exemplo de vida e força a serem seguidos e ao meu avô Ary que continua a me iluminar de onde quer que esteja.

À minha irmã Fabianna, amiga de todas as horas, por estar ao meu lado quando mais precisei, por todo seu carinho e principalmente por todos os bons momentos que passamos juntas.

Aos meus queridos pais por me ensinarem a lutar por tudo aquilo em que acredito e por estarem sempre ao meu lado, especialmente nas horas difíceis.

A todos aqueles que, de alguma forma, colaboraram para a realização deste trabalho.

E a minha eterna gratidão aos animais que participaram desse trabalho e tornaram possível a sua concretização. 


\section{SUMÁRIO}

Página

LISTA DE FIGURAS........................................................................... viii

LISTA DE TABELAS ..................................................................... $\mathrm{x}$

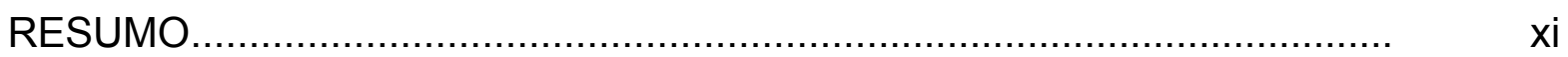

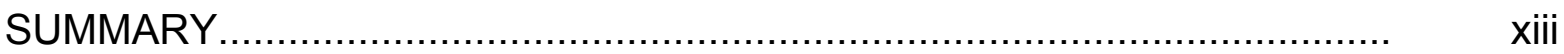

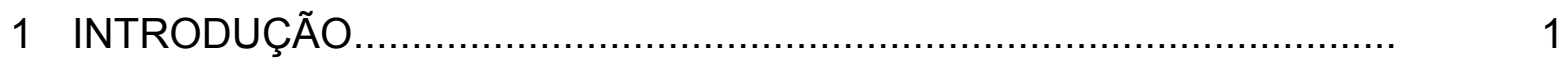

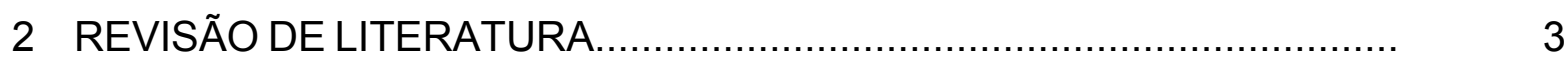

2.1 Carnes de animais silvestres........................................................ 3

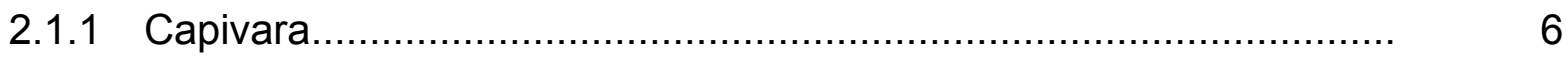

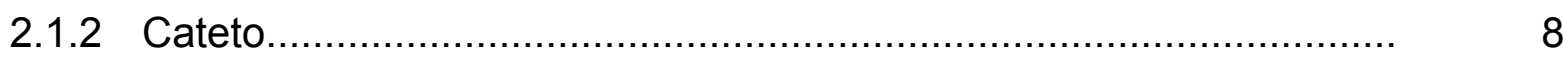

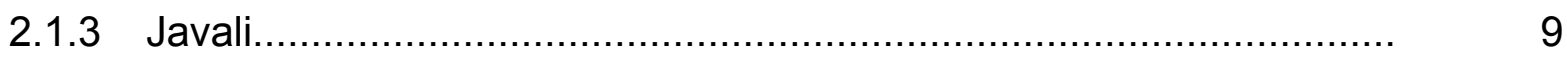

2.2 Riscos microbiológicos da carne ......................................... 10

2.3 Salmonella............................................................................. 14

$2.4 \quad$ Coliformes Totais e Fecais.......................................................... 16

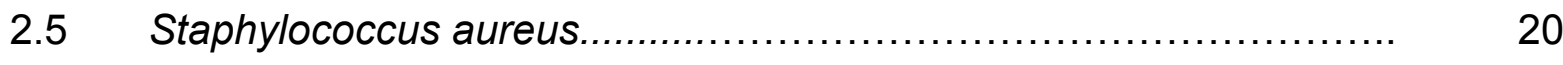

$2.6 \quad$ Clostridium ....................................................................... 23

2.7 Mesófilos e Psicrotróficos totais..................................................... 25

3 MATERIAL E MÉTODOS.............................................................. 26

3.1 Meios de Cultivos Utilizados.................................................... 26

3.1.1 Agar Padrão para Contagem (PCA)......................................... 26

3.1.2 Caldo Lauril Sulfato Triptose (LST) ............................................... 26

3.1.3 Caldo Verde Brilhante Lactose Bile 2\% (CVBLB)........................... 27 


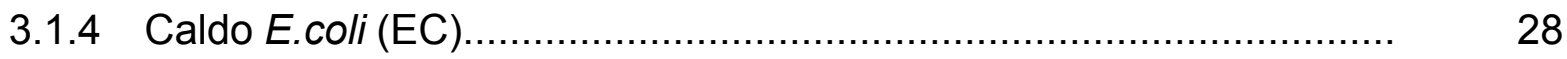

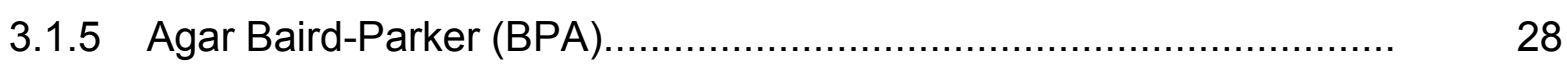

3.1.6 Sulfito-Polimixina-Sulfadiazina-Agar (SPS-A)................................. 29

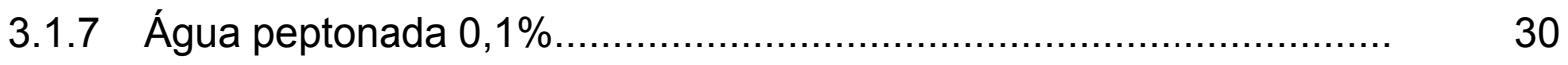

3.1.8 Kit "Oxoid Salmonella Rapid Test e seus meios.............................. 31

3.1.9 Equipamentos e vidraria tradicionalmente utilizados em laboratório de microbiologia................................................................. 32

3.2 Obtenção das carnes............................................................. 32

3.3 Preparo das amostras............................................................ 32

3.4 Análises microbiológicas.............................................................. 33

3.4.1 Contagem total de aeróbios mesófilos e psicrotróficos..................... 33

3.4.2 Número mais provável (NMP) de coliformes totais e fecais.............. 35

3.4.3 Presença/Ausência de Salmonella.................................................... 38

3.4.4 Contagem de Staphylococcus aureus............................................ 42

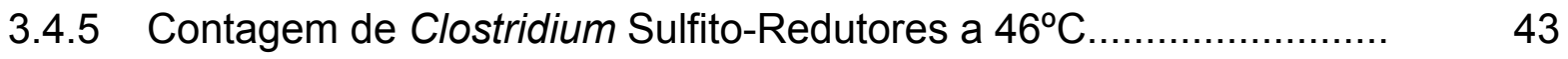

3.5 Análise estatística................................................................... 45

4 RESULTADOS E DISCUSSÃO.................................................... 46

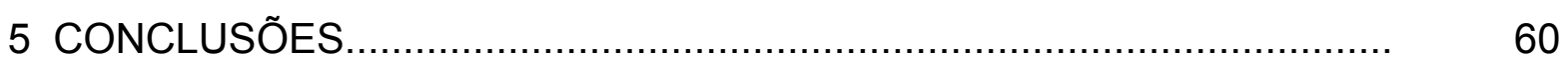

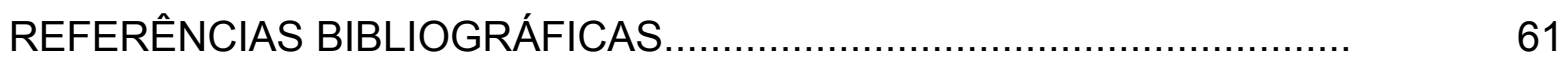




\section{LISTA DE FIGURAS}

Página

$1 \quad$ Procedimento para o preparo das diluições............................... 35

$2 \quad$ Procedimento para contagem total de mesófilos e psicrotróficos........ 36

3 Procedimento para a estimativa do NMP de coliformes totais e fecais.

4 Preparo e inoculação do kit "Oxoid Salmonella Rapid Test".

5 Leitura e interpretação dos tubos A (a) e B (b) para análise de Salmonella.

6 Procedimento para a contagem de Staphylococcus aureus.

7 Procedimento para a contagem de Clostridium Sulfito-Redutores a $46^{\circ} \mathrm{C}$

8 Contagem total de microrganismos mesófilos aeróbios nas carnes de capivara, cateto e javali in natura.........................................

9 Contagem total de microrganismos psicrotróficos nas carnes de capivara, cateto e javali in natura. 
10 Contagem de S.aureus nas carnes de capivara, cateto e javali in

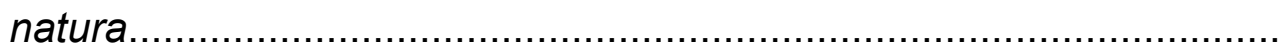

11 Contagem de Clostridium sulfito-redutores nas carnes de capivara, cateto e javali in natura

12 Número Mais Provável (NMP) de coliformes totais nas carnes de

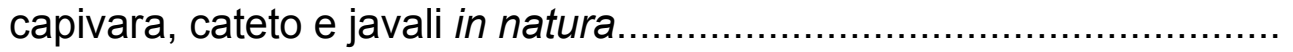

13 Número Mais Provável (NMP) de coliformes fecais nas carnes de capivara, cateto e javali in natura

14 Presença/Ausência de Salmonella nas carnes de capivara, cateto e

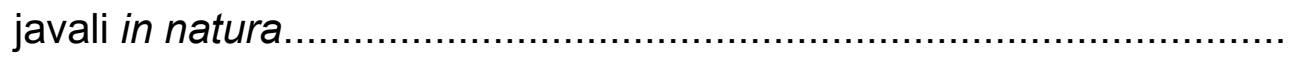




\section{LISTA DE TABELAS}

Página

1 Número mais provável para várias combinações de resultados positivos, quando três tubos são utilizados por diluição (inoculações de 1, 0,1 e 0,01 g ou $\mathrm{mL}$ da amostra).....................

2 Contagem total de microrganismos mesófilos aeróbios nas carnes de capivara, cateto e javali in natura.................................

3 Contagem total de microrganismos psicrotróficos nas carnes de capivara, cateto e javali in natura

4 Contagem de S. aureus nas carnes de capivara, cateto e javali in natura

5 Contagem de Clostridium sulfito-redutores nas carnes de capivara, cateto e javali in natura

6 Número mais provável (NMP) de coliformes totais nas carnes de capivara, cateto e javali in natura.......................................

$7 \quad$ NMP de coliformes fecais nas carnes de capivara, cateto e javali

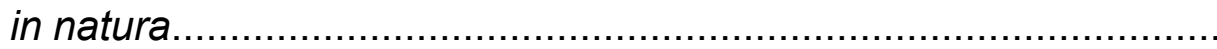

8 Coeficientes de variação (\%) 


\title{
AVALIAÇÃO DAS CONDIÇÕES MICROBIOLÓGICAS DE CARNES DE ANIMAIS SILVESTRES NO MUNICÍPIO DE SÃO PAULO
}

\author{
Autora: Flávia Sarkis \\ Orientador: Prof. Dr. Cláudio Rosa Gallo
}

\section{RESUMO}

O interesse por espécies animais não convencionais, para a suplementação de proteína animal, é crescente, particularmente nos países africanos e asiáticos, porém, a utilização dessas fontes de alimento ainda é pouco documentada e quase não se sabe sobre as condições microbiológicas das carnes disponíveis para consumo. Este estudo avaliou as condições microbiológicas das carnes de capivara (Hydrochaeris hydrochaeris), cateto (Tayassu tajacu) e javali (Sus scrofa scrofa) in natura comercializadas no Brasil, município de São Paulo. Um total de vinte e sete amostras de carne de capivara, cateto e javali foram analisadas em laboratório e verificado o grau de contaminação por mesófilos aeróbios totais, psicrotróficos, Staphylococcus aureus, Clostridium sulfito-redutores, coliformes totais e fecais e Salmonella. 22\% das amostras de carne de cateto apresentaram-se impróprias para o consumo humano devido à presença de Salmonella. $11 \%$ das amostras das carnes de capivara e javali e $22 \%$ das amostras de cateto apresentaram contagens elevadas de $S$. aureus, maiores que o limite máximo estabelecido pela resolução RDC n¹2 da Agência Nacional de Vigilância Sanitária (ANVISA) de 02 de janeiro de 2001, para produtos cárneos crus, resfriados ou congelados, uma vez que a resolução 
não cita tais padrões para carne in natura. Por apresentarem contagem de $S$. aureus superiores aos padrões estabelecidos, tais amostras são consideradas em condições higiênico-sanitárias insatisfatórias. A análise estatística descritiva apresentou um elevado coeficiente de variação entre as 9 amostras analisadas para cada tipo de carne. Esse alto grau de variação mostra que as condições microbiológicas das amostras não apresentaram uniformidade no decorrer das análises. 


\title{
EVALUATION OF MICROBIOLOGICAL CONDITIONS OF WILD MEATS IN SÃO PAULO CITY
}

\author{
Author: Flávia Sarkis \\ Adviser: Prof. Dr. Cláudio Rosa Gallo
}

\section{SUMMARY}

The interest for non-conventional animal species, for the supplementation of animal protein is growing, although this food source is little documented. This study has evaluated the microbiological conditions of capybara (Hydrochaeris hydrochaeris), collared peccary (Tayassu tajacu) and wild boar (Sus scrofa scrofa) raw meat sold in São Paulo city. A total of twenty-seven samples were evaluated in a laboratory to find out the contamination value by: mesophiles aerobic, psychrotrophs, Staphylococcus aureus, Clostridium sulfito-redutores, coliforms group and Salmonella. $22 \%$ of collared peccary meat samples were improper to human consumption due to the Salmonella presence. $11 \%$ of the samples of the capybara meats and boar and $22 \%$ of the collared peccary samples presented high counting of $S$. aureus, larger than the maximum limit established by the resolution RDC $n^{0} 12$ of the National Agency of Sanitary Surveillance (ANVISA) of January 02, 2001, for raw meat products, colds or frozen, once the resolution doesn't mention such patterns for raw meat. These samples showed unsatisfactory hygenic-sanitary conditions by presenting $S$. aureus counting higher than the maximum limit. 


\section{INTRODUÇÃO}

O interesse por espécies animais não convencionais, para suprimento de proteína animal, é crescente, porém a utilização dessas fontes de alimento ainda é pouco documentada (Féron, 1995).

No Brasil, assim como em outros países da América Latina, África e Ásia, a fauna silvestre representa uma importante fonte protéica para a alimentação humana, principalmente nas regiões mais carentes. Nos grandes centros urbanos as carnes desses animais são comercializadas em restaurantes e "boutiques de carnes" por preços elevados.

Alguns estudos já foram realizados com o objetivo de verificar a viabilidade da produção de carnes silvestres. As espécies mais estudadas são: capivara , avestruz, javali, jacaré, cateto e queixada, entre outros.

O continente africano apresenta o maior número de habitantes dependentes da fauna silvestre. De acordo com Silva Neto (1990) o consumo de carne de caça na África é de 13,9 g/ pessoa / dia em Kinshasa, 27,0 g/ pessoa / dia na Costa do Marfim, 44,9 g/ pessoa / dia no Kalahari e 37,2 g/ pessoa/dia na região do delta do rio Niger na Nigéria.

$\mathrm{Na}$ Venezuela é comum o consumo da carne de capivara pois os católicos foram autorizados a comer esta carne durante o período da quaresma, o que se tornou uma tradição. Esta carne tem sido estudada há vários anos, principalmente quanto a possibilidade de industrialização. Como resultado tem-se obtido excelentes produtos como salsichas e mortadelas (Jiménez, 1977).

De acordo com Ojasti (1991) são abatidas legalmente, na Venezuela, 30 a 50 mil capivaras por ano e são destinadas ao processamento 
de carne salgada com produção de 400 toneladas. Já a Colômbia, produziu na década de 60, cerca de 281 toneladas de carne de capivara/ ano. O autor aborda ainda que a carne salgada era vendida na Venezuela, em 1991, por US $\$ 3,50 / \mathrm{Kg}$.

No Brasil predomina a caça predatória e ilegal. Por serem animais pertencentes à fauna silvestre brasileira, estão protegidos pela lei de Proteção à fauna (Lei 5.197, de 03 de janeiro de 1967), que proíbe a caça, transporte e comercialização de animais silvestres no Brasil, sendo o Instituto Brasileiro do Meio Ambiente e dos Recursos Naturais Renováveis - IBAMA, quem atualmente regulamenta a exploração econômica desses animais através de portarias. Porém, devido às falhas na fiscalização esses produtos têm seu preço aumentado no mercado ilegal e há perda de divisas para o país (Silva Neto, 1990).

Por outro lado, é visível o aumento de criações comerciais de animais silvestres no país, impulsionado pelo mercado em expansão das carnes exóticas e do couro.

O presente estudo teve por objetivo avaliar a qualidade microbiológica das carnes de capivara, cateto e javali in natura, comercializadas em estabelecimento devidamente autorizado, no município de São Paulo. 


\section{REVISÃO DE LITERATURA}

A carne, o leite e os ovos constituem as fontes básicas de proteína animal, devido sobretudo ao seu valor biológico. Há os que, inclusive, caracterizam o nível de consumo de proteínas de origem animal, em especial as de carne, como elemento indicativo do desenvolvimento socioeconômico de um povo (Pardi et al., 1993).

Apesar da proteína animal ser a mais difundida e a de melhor qualidade, sua baixa produção e elevado preço, fazem com que grande parte da população não tenha acesso a esse tipo de alimento.

O mundo pode ser dividido em duas partes de acordo com a demanda de carne: os chamados países desenvolvidos e as áreas em desenvolvimento. No mundo desenvolvido a oferta de carne de animais domésticos normalmente excede a demanda. Por outro lado, nos países em desenvolvimento, o acesso à carne está freqüentemente abaixo do padrão adequado de nutrição, em uma larga camada da população (Kyle, 1994).

\subsection{Carnes de animais silvestres}

O consumo de carnes de animais silvestres tem aumentado, assim como a exploração econômica racional da fauna.

Segundo Silva Neto (1990) em países da Europa, África e nos Estados Unidos a fauna silvestre é explorada com o objetivo de fornecer lucro àqueles que desenvolvem esse tipo de produção. $O$ continente africano é o que 
apresenta o maior número de habitantes dependentes da fauna silvestre. Já no Brasil o consumo é mais significativo apenas em regiões de baixa renda.

No Pará, região da Transamazônica, são consumidas aproximadamente $264 \mathrm{~g} /$ pessoa / dia de carne de animais silvestres (Smith, 1976).

Silveira \& Thorbjarnarson (1999) verificaram a caça e venda de carne de jacaré na reserva Mamirauá, na Amazônia. A maioria da carne era vendida na Colômbia como populares espécies de peixes como pirarucu ou bagre-do-canal. Os autores abordam que, de janeiro a abril de 1995 aproximadamente 13 toneladas de carne de jacaré foram comercializadas.

Vicentini (2000) estuda a carne de avestruz e a descreve como tendo coloração avermelhada e excelente sabor, além de possuir baixos teores de colesterol e de gordura. $\mathrm{O}$ autor ainda aborda que o avestruz pode chegar a $100 \mathrm{~kg}$ e produzir 30 a $40 \mathrm{~kg}$ de carne. No mercado americano a carne de avestruz chega a custar 10 a $20 \%$ mais que a carne bovina nos supermercados. Nesse país existem abatedouros especializados na distribuição da carne em restaurantes e supermercados na forma de congelados.

Assim como a carne de avestruz, outras carnes silvestres apresentam baixo teor de gordura. Leak et al. (1987) verificaram que a baixa porcentagem de gordura e a alta porcentagem de umidade da carne de crocodilianos tornam esse produto delicado em textura, podendo sofrer danos de congelamento. A gordura dessa carne apresenta uma maior porcentagem de ácidos graxos insaturados quando comparada às carnes de boi e suíno.

Estudos realizados com carne de outros animais silvestres também mostram maiores teores de proteína em relação as fontes convencionais. Onyango et al. (1998) concluíram que as perdas de proteína na cocção são maiores em carnes bovinas do que na carne de zebra para o mesmo corte. 
Apesar da excelente qualidade nutricional, um fator que limita a utilização deste recurso animal é a possibilidade de que esses animais sejam portadores de doenças, apresentando riscos à saúde humana.

Hoffman \& Romanelli (1998), analisando carne de jacaré do Pantanal, detectaram Staphylococcus aureus e Salmonella sp. em todas as amostras, classificando essa carne como imprópria para o consumo humano. Os autores relatam ainda que, antes da análise, procedeu-se à imersão da carcaça em solução de hipoclorito de cálcio a 100 ppm durante 1 minuto, como provável forma de atenuar a presença de microrganismos, o que não surtiu efeito. Os autores sugerem aumento no tempo de imersão e/ou concentração do hipoclorito de cálcio, e também algumas modificações no manuseio e na linha de abate para obter condições adequadas para comercialização e consumo.

Leak et al. (1987), também pesquisando carne de jacaré, verificaram a presença de Salmonella sp. e Escherichia coli nas amostras. A carne da cauda apresentou maior contaminação do que as carnes do lombo e das costelas. Scott \& Foster (1997) verificaram maior presença de Salmonella sp. em animais provenientes de criação em cativeiro (ocorrendo em $20 \%$ das amostras) do que em animais provenientes da natureza (ocorrendo em 2,8\% das amostras).

O tipo de criação (criatório) também pode ter grande contribuição na prevalência de Salmonella sp, como relatam Scott \& Foster (1997), e essa carne contaminada pode causar doenças em humanos, havendo, portanto, a necessidade de cuidados especiais quando a carne é preparada para consumo.

Adesiyun et al. (1998) compararam a incidência de Salmonella em animais silvestres criados em cativeiro e em sistema de manejo semiaberto. Os animais criados em cativeiro apresentaram uma maior incidência de Salmonella spp. Os autores atribuem o fato ao confinamento, dieta, e proximidade com humanos. 
Estudo realizado por Piérard et al. (1997) mostrou que a contaminação com $E$. coli é maior em animais silvestres ruminantes do que em silvestres mamíferos não ruminantes. Vinte e sete porcento das amostras de javali analisadas foram positivas para verocitotoxina, produzida pela E.coli.

Um surto de diarréia sanguinolenta foi reportado em novembro de 1997, na região africana de Camarões. Até março de 1998 o número de casos chegava a 237, com 44 mortes. Os patógenos envolvidos foram Escherichia coli 0157:H7 e Shigella. Alguns casos do surto foram atribuídos ao consumo de carne silvestre defumada (Germani et al., 1998).

Os animais silvestres podem ser também portadores de muitos parasitas. Arias et al. (1997) concluíram que a capivara é um reservatório natural de Tripanosoma evansi, encontrando até $63 \%$ dos animais analisados infectados.

Outro fator que limita o consumo dessas carnes no Brasil é a crendice popular. Estudo realizado por Trigo et al. (1989) mostra que, principalmente em regiões de nível educacional limitado, há formação de hábitos e tabus alimentares, associados à religiosidade.

$\mathrm{Na}$ região Norte do país, $51 \%$ das mães entrevistadas alegaram não comer carne de caça durante o período da lactação dando justificativas como "dá coceira", "dá demência", "envenena", entre outras.

\subsubsection{Capivara}

A capivara é o maior roedor do mundo com mais de $100 \mathrm{~cm}$ de comprimento por $50 \mathrm{~cm}$ de altura, pesando em média $50 \mathrm{Kg}$.

Os pêlos são ásperos, de cor castanha escuro, ocre ou amarelo queimado. Existe uma variação de cores que acompanha o aumento de peso. Acredita-se que essa variação de cores possa estar relacionada com o meio ambiente no qual o animal vive e também com sua maior ou menor exposição aos raios solares (Silva, 1986). 
Este animal move-se agilmente em terra firme, podendo correr de 100 a 200 metros, com pausas, porém se cansa facilmente caindo em hipertermia. É um animal de hábitos noturnos, como a maioria dos herbívoros, pastando durante as primeiras horas do dia e ao entardecer. Alimenta-se principalmente de forragens e plantas aquáticas.

Uma capivara fêmea produz em média 4 a 6 filhotes por cria, podendo ter até duas crias por ano e atinge a maturidade sexual aos 18 meses (Jiménes, 1977; Kyle, 1994).

Em São Paulo, até o ano de 1996, a carne da capivara era vendida pelo produtor por US\$ $8,00 / \mathrm{kg}$, chegando ao consumidor por até US\$ 20,00/ kg (Silva Neto, 1996).

Pesquisa realizada por Frasson \& Salgado (1990) mostra que a carne de capivara apresenta um teor de gordura mais baixo do que a carne bovina. A pesquisa ainda mostra que os teores de proteínas na carne de capivara (lombo, traseiro e dianteiro) são 12,63\% superiores aos da carne bovina (alcatra) e $11,67 \%$ superiores aos de carne suína (lombo, traseiro e dianteiro).

Santos et al. (1986) analisando a composição de ácidos graxos da gordura da capivara verificaram que sua natureza e estado físico líquido a $20^{\circ} \mathrm{C}$ é devido a grande participação dos ácidos graxos insaturados na sua composição, principalmente ácidos oleico $(35,64$ - 39,88\%) e palmítico $(20,56-24,32 \%)$. Os autores constataram também que o odor e o paladar típico desta gordura é ocasionado pela presença de ácidos graxos de baixo peso molecular, como o butírico e o capróico.

Quanto as condições sanitárias dessa carne, Lord \& Flores (1983) afirmam que a capivara pode ser um importante reservatório de Brucella spp. Análises realizadas mostraram que os animais tornam-se infectados muito jovens, sendo $48 \%$ dos animais com menos de 1 ano portadores da bactéria. Os autores também verificaram que a incidência varia de acordo com a região. 
Quando comercializadas, as carnes de capivara podem apresentar-se em diversas formas. Podem ser encontradas na forma de lingüiças, como mostram as pesquisas sobre o assunto. Outra forma de comercialização seria a salgada, que parece ser a mais utilizada nas regiões brasileiras mais carentes, onde não há energia elétrica, para permitir uma longa armazenagem do produto (Silva,1986).

Experimento realizado por Salgado et al. (1999) mostra que a carne de capivara pode também pode ser utilizada na elaboração de produtos cárneos como salsicha e fiambre. Os autores compararam a salsicha e o fiambre elaborados a partir da carne de boi + porco e a da carne de boi + capivara. De acordo com a análise sensorial não houve diferença estatística entre os produtos, com exceção do atributo sabor de fiambre, onde o fiambre teste recebeu uma pontuação significativamente menor que o fiambre controle.

\subsubsection{Cateto}

O Cateto é um mamífero onívoro, com comprimento que varia de 0,75 a $1,0 \mathrm{~m}$, altura de cernelha de 0,40 a $0,50 \mathrm{~m}$ e peso adulto entre $14 \mathrm{e}$ $30 \mathrm{~kg}$ (Nowak \& Paradiso, 1983). Vivem em bandos, geralmente com 5 a 15 membros, toda sua vida, tendo uma organização social permanente (Byers \& Bekoff, 1981).

Segundo Sowls (1984), seus pêlos são longos, ásperos, espessos e com várias anelações pretas e brancas, sendo a pelagem preta com estrias esbranquiçadas, apresentando um colar de pêlos brancos que se estende desde a frente da paleta até a crina na região dorsal.

Esses animais vivem em uma grande variedade de habitats, incluindo regiões de clima árido e florestas tropicais úmidas, atingindo latitudes Norte e Sul (Nowak \& Paradiso, 1983), sendo observados também em áreas próximas a grandes centros urbanos (Bellantoni \& Krausman, 1993), podendo se alimentar com uma ampla variedade de alimentos como pastagens, sementes, frutos e tubérculos. Em regiões secas, o cactus é o principal alimento 
para os catetos, funcionando também como fonte de água (Corn \& Warren, 1989).

Redford \& Robinson (1992) colocam os catetos e as queixadas entre as principais fontes de proteína animal para populações indígenas e de colonos na região Amazônica.

Gruver \& Guthrie (1996) analisaram amostras de sangue de cateto e constataram que na região do Texas, os animais não apresentaram anticorpos contra Brucella spp., mas $6 \%$ dos animais apresentaram anticorpos contra Yersinia pestis. Já Lord \& Lord (1991), analisando tecidos de catetos na Venezuela encontraram $31 \%$ de amostras positivas para Brucella suis. Os autores concluíram também que animais mais jovens mostraram taxas mais baixas e que podem ter sido contaminados por capivaras.

\subsubsection{Javali}

O javali é um animal muito antigo, tendo sua origem no norte da África e sudoeste da Ásia. Na América é considerado um animal exótico.

Sua capacidade de adaptação às diversas regiões do globo para onde migrou é uma característica importante para a sua sobrevivência. Sua longevidade é de 20 anos e o animal adulto pesa em média de 150 a 280 $\mathrm{Kg}$, com comprimento de 125 a $180 \mathrm{~cm}$ e altura de 75 a $120 \mathrm{~cm}$ (www.jcprada.com.br). O período de gestação das fêmeas é de 121 dias, com ninhadas de 6 filhotes, em média.

A carne de javali é apreciada em todo o mundo por ser muito saborosa. Na Idade Média o javali era considerado um dos mais cobiçados troféus de caça. A qualidade nutricional da carne é excelente, apresentando baixos teores de lipídeos e colesterol, inferiores aos do peito de frango (www.sambaqui.com.br).

No Japão, as carnes de caça são vendidas para consumo principalmente no inverno, quando são capturadas na estação de caça de inverno. Kanai et al. (1997), analisaram essas carnes e verificaram que Yersinia 
enterocolitica estava presente em $38,7 \%$ das amostras de carne de javali e em $33,3 \%$ das amostras de cervo. Salmonella foi detectada em 2 das 93 amostras de carne de javali analisadas.

Gibbs (1997) relata a ocorrência de Salmonella em carne de javali preparada para consumo humano na Austrália. O mesmo autor ainda afirma que não há evidência de que javalis sejam naturalmente contaminados pela E.coli O157:H7.

Boers et al. (1994) compararam a vida útil da carne de javali com a carne de porco. Os autores concluíram, através de analises sensoriais e microbiológicas, que a carne de javali embalada à vácuo possui uma vida útil muito maior do que a carne suína nas mesmas condições.

\subsection{Riscos microbiológicos da carne}

Chipley \& Cremer (1980) relatam que, em 1977, 46,5\% dos surtos de toxinfecções alimentares confirmados nos EUA envolveram serviços de alimentação, e em 1978, este valor foi de $89,8 \%$. No Brasil, praticamente inexistem dados e levantamentos epidemiológicos que demonstrem a incidência e a gravidade das toxinfecções de origem alimentar (Leitão, 1978).

A Organização Mundial da Saúde (OMS) define a higiene dos

alimentos como o "conjunto de medidas destinadas a garantir ou reforçar a comestibilidade e a segurança para consumo humano de determinados alimentos ou de alimentos em geral, com a abrangência de todos os aspectos da produção, colheita, elaboração, distribuição e preparação dos alimentos, bem como de todas as possíveis causas de toxicidade (física, química ou microbiológica)".

Matyas (1979) endossa a definição adotada pelo Programa de Padrões dos Alimentos da FAO/OMS, preparada pelo Codex Alimentarius: "A higiene dos alimentos compreende todas as medidas necessárias para garantir 
segurança, salubridade e sanidade do alimento em todos os estágios de seu desenvolvimento, produção ou manufatura até seu consumo final".

Ao comentar a reformulação, pelo Ministério da Saúde, dos padrões microbiológicos de alimentos, Mello (1987) a esclarece sinteticamente nos seguintes termos: "Dentro do contexto de relevância para proteção à saúde, os limites de microrganismos foram estabelecidos visando à boa qualidade higiênica do alimento e daquelas bactérias cuja ação patogênica está vinculada ao número de microrganismos, quer seja para produção de toxinas em níveis capazes de iniciar sintomas de intoxicação, ou daquelas cuja multiplicação torna-se significativa para desencadear um processo infeccioso".

A Agência Nacional de Vigilância Sanitária (ANVISA), através da Resolução - RDC n¹2, de 02/01/01, fixa limites de tolerância para diversos produtos cárneos.

O Ministério da Agricultura estabelece que todo estabelecimento onde é permitida a matança de bovinos, eqüídeos, suínos, ovinos, caprinos e coelhos, bem como das diferentes aves domésticas e de caça, usadas na alimentação humana, está subordinado à Inspeção Federal. Não há, no entanto qualquer referência quanto as condições do abate de animais silvestres no documento.

A Resolução $n^{\circ} 12$ da ANVISA de 02 de janeiro de 2001, define como produtos em condições sanitárias satisfatórias, os que apresentam resultados analíticos abaixo ou igual aos estabelecidos para amostra indicativa ou amostra representativa. Produtos em condições sanitárias insatisfatórias, são definidos como os que apresentam resultados analíticos acima dos limites estabelecidos para a amostra indicativa ou produtos cujos resultados analíticos demostram a presença ou a quantificação de outros microrganismos patogênicos ou toxinas que representem risco à saúde humana.

Os limites estabelecidos pela mesma Resolução para produtos cárneos crús resfriados ou congelados, como lingüiças, quibes, almôndegas e hambúrguer, são: ausência de Salmonella em $25 \mathrm{~g}$ de produto; número mais 
provável (NMP) máximo de coliformes fecais de $5,0 \times 10^{2} / g$ de produto; unidades formadoras de colônias (UFC) ou NMP máximo de $S$. aureus de 1,0 x $10^{3} / \mathrm{g}$ de produto; e Clostrídios sulfito redutores máximo de $5,0 \times 10^{2} / \mathrm{g}$ de produto. Embora esta Resolução não faça referência a contagem total de aeróbios, a Comissão Nacional de Normas e Padrões para Alimentos (1978), estabelecia como valor máximo para contagem total em placas, 3,0 × $10^{6}$ UFC/g, para produtos cárneos crus resfriados ou congelados. Já para carnes cruas a Resolução cita apenas ausência de Salmonella em $25 \mathrm{~g}$ de carne.

No caso particular de higiene de carnes, tais cuidados tem início com o animal vivo, envolvendo inclusive dados anteriores representados pela procedência, cuidados sanitários a que se submeteram, características dos meios de transportes e, em certas condições, até particularidades de ordem zootécnica, como a natureza da alimentação e do manejo recebidos (Pardi et al., 1993).

Como fontes potenciais de contaminação nos matadouros, contam-se as peles e os pêlos dos animais impregnados de sujidades e fezes, que podem carregar milhões de bactérias aeróbias e anaeróbias. Tal contaminação depende: do tipo de solo das pastagens, da higiene dos animais, do ar e poeira, da água utilizada na lavagem da carcaça, dos equipamentos e do ambiente, dos utensílios, dos vários recipientes usados e do próprio pessoal no trabalho. Merece referência especial a contaminação por conteúdo gastrintestinal.

Sharf (1972) relata que os microrganismos contaminam a carne a começar do próprio animal. Os contaminantes podem ser disseminados durante as diferentes fases do preparo da carcaça, no ato da sangria, esfola, na evisceração e durante a limpeza ou toalete.

De acordo com Tompkin (1983), a contagem total de aeróbios, de coliformes totais e de Escherichia coli constituem-se indicadores de qualidade sanitária de utilização mais comum para produtos cárneos. 
Os mesófilos são importantes porque indicam o grau de higiene durante o processo de abate. Os coliformes totais, E. coli, enterococos, $S$. aureus, Clostridium perfringens e Salmonella estarão sempre presentes nos tecidos frescos quando o processo de abate não incluir um estágio de tratamento com bactericida (Neder,1992) ${ }^{1}$.

Toxinfecções alimentares por microrganismos:

Genigeorgis (1986) mostra que a salmonelose permanece como uma das três doenças de origem alimentar mais comuns nos EUA. Está sendo apenas realista alguém que admite que qualquer carne que chega a uma cozinha doméstica ou institucional ou mesmo a uma planta processadora esteja contaminada com Salmonella e deva ser manuseada como tal. Segundo Johnston (1983), as impropriedades, em nível de fábrica incluem subaquecimento, contaminação cruzada, resfriamento impróprio e cura inadequada.

Bandarra et al. (1995) relatam caso de septicemia por Salmonella sp. em capivara. O animal fêmea, adulta e aparentemente sadia foi capturado na natureza sofrendo morte súbita após 45 dias de captura.

Todos os surtos de origem alimentar atribuídos a linhagens de Escherichia coli são direta ou indiretamente ligados à contaminação fecal humana. Isto é, como lembram Doyle \& Schueni (1984), supõe-se que o alimento tenha sido exposto à água não tratada e contaminada por esgoto doméstico, ou a um manipulador contaminado.

Tompkin (1980) sumarizou os surtos de botulismo ocorridos nos EUA, Canadá e outros países, de 1899 a 1979, mediante consumo de produtos cárneos e avícolas. Ele relatou ainda nove surtos devidos a carnes processadas comercialmente e 51 devido a carnes processadas em ambiente domiciliar, nos EUA e Canadá, durante os anos de 1960 a 1979.

\footnotetext{
${ }^{1}$ NEDER, R.N. Microbiologia e deterioração de carnes. In: Microbiologia de Alimentos I. Piracicaba : CALQ, 1992. p.132-134.
} 


\subsection{Salmonella}

As salmonelas são bactérias em forma de bastonetes, Gram negativos, anaeróbios facultativos, pertencentes a família Enterobacteriaceae (Hajdenwurcel, 1998).

O habitat natural de Salmonella é o trato intestinal de humanos e de outros animais. A água e alimentos de origem animal têm sido identificados como veículos de transmissão deste microrganismo (Cliver,1990).

As salmonelas desenvolvem-se bem a valores de atividade de água de 0,945 a 0,999. Suportam uma faixa de $\mathrm{pH}$ entre 4,5 e 9,0 com um ótimo de 6,5 a 7,5 , sendo que, sua temperatura ótima de crescimento se encontra entre 35 e $37^{\circ} \mathrm{C}$. No entanto, as salmonelas podem multiplicar-se desde $5^{\circ}$ até $45-47^{\circ} \mathrm{C}$. Nota-se que a pasteurização a $72^{\circ} \mathrm{C}$ por 15 segundos assegura a sua destruição (Hajdenwurcel, 1998).

Segundo Eley (1994), a salmonelose surgiu como um problema de saúde pública no Reino Unido pouco depois da Segunda Guerra Mundial, sendo introduzida na cadeia alimentar principalmente por meio de lotes de ovos desidratados contaminados, vindos dos EUA. Durante os anos 60 e 70 ocorreu um aumento nos casos e surtos de salmoneloses na maioria dos países da Europa e América do Norte, veiculados por uma ampla variedade de alimentos.

Nos animais, os sorotipos mais comuns são $S$. typhimurium (na maioria das espécies), S. dublin (em vacas), S. montevideo (ovelhas) e $S$. enteritidis, em aves (Eley,1994). Cliver (1990), relata que os sorotipos $S$. urbana, S. litchfield e $S$. java, apresentam-se com alta incidência em tartarugas.

A patologia pode ser manifestada de duas maneiras (Hajdenwurcel, 1998):

- Febre Tifóide e Paratifóide: São causadas pela Salmonella choleraesuis sorotipo typhi e S. choleraesuis sorotipo paratyphi A,B e C 
respectivamente. Afetam primatas (seres humanos e macacos) de modo praticamente exclusivo, sendo as salmonelas disseminadas pela água $\mathrm{e}$ alimentos. A dose de infecção é baixa, o período de incubação longo, desenvolvendo-se um quadro clínico caracterizado por septcemia, normalmente sem gastroenterite, sendo ainda freqüente a ocorrência da situação de portador assintomático por períodos bastante longos. A Salmonella typhi penetra na mucosa intestinal e atinge o sistema linfático, onde é engolfada pelos fagócitos, multiplicando-se em seu interior, sendo que as manifestações clínicas somente ocorrem quando a bactéria deixa estas regiões intracelulares e penetra na corrente sangüínea.

- Gastroenterite ou Salmonelose: Nos casos de gastroenterites, o período de incubação varia de 12 a 24 horas em média e os principais sintomas são febre $\left(38\right.$ a $39^{\circ} \mathrm{C}$ ), diarréia mucosa, por vezes com sangue e tenesmos, dores abdominais, náuseas, vômitos, sendo que os sintomas persistem por 2 a 5 dias.

As formas septicêmicas existem tanto no homem como nos animais. Após ingestão do alimento e a passagem através do ambiente ácido do estômago, elas atingem o intestino delgado, invadindo o lúmen, onde se multiplicam; posteriormente atingem o íleo e, em menor proporção, o cólon, onde desenvolvem uma reação inflamatória.

Segundo Rumeu et al. (1997), o mecanismo de ação da Salmonella, que induz o aparecimento de doenças diarréicas, é complexo e pode envolver a interação de uma série de mecanismos como a produção de enterotoxinas, citotoxinas e invasividade nas mucosas, além do processo inflamatório.

Os alimentos de origem animal são os mais freqüentemente envolvidos em casos ou surtos de salmoneloses, entre eles as carnes, os ovos, o leite e derivados do leite não "tratados" e qualquer produto susceptível de sofrer contaminação fecal (Eley,1994), além de produtos de panificação e confeitaria e saladas diversas (Hajdenwurcel, 1998). 
Madsen (1996) analisando carnes de crocodilo do Nilo frescas e congeladas detectou esta bactéria em $30 \%$ e $20 \%$ das amostras respectivamente.

Ao examinar duzentas carcaças de carneiro provindas de abatedouro convencional, abatedouro moderno e açougue, Narasimha (1983) detectou presença de Salmonella em 9 e $8 \%$ das amostras do abatedouro convencional e do açougue respectivamente. $O$ autor atribui a alta incidência de Salmonella à manipulação incorreta durante o abate e evisceração das ovelhas, uma vez que o microrganismo não foi detectado nas carcaças processadas no abatedouro moderno.

Reis et al. (1995) analisando 50 amostras de produtos cárneos isolaram Salmonella em $26 \%$ destas. A maior contaminação aconteceu nas amostras de salsicha, que foi de $44,4 \%$. Já nas amostras de fígado bovino o microrganismo não foi detectado. Os autores analisaram ainda lingüiça frescal e quibe cru verificando a presença de Salmonella em 35,3 e $30 \%$ das amostras respectivamente.

Já Pelayo \& Saridakis (1988) também examinando quibe crú detectaram Salmonella em 6,45\% das amostras.

Hofer et al. (2000) analisaram amostras de carne de eqüideos (eqüinos e asininos) e detectaram Salmonella em 3,4\% das amostras. Entre os 98 sorovares caracterizados o mais incidente foi o anatum, presente em 19,8\% das amostras contaminadas.

\subsection{Coliformes Totais e Fecais}

O grupo dos coliformes totais inclue as bactérias na forma de bastonetes Gram negativos, não esporogênicos, aeróbios ou anaeróbios facultativos, capazes de fermentar a lactose com produção de gás, em 24 a 48 horas a $35^{\circ} \mathrm{C}$. O grupo inclui cerca de 20 espécies, dentre as quais encontramse tanto bactérias originárias do trato gastrintestinal de humanos e outros 
animais de sangue quente, como também diversos gêneros e espécies de bactérias não entéricas, como Serratia e Aeromonas, por exemplo (Silva et al.,1997).

Porém, a presença de coliformes totais em alimentos processados é considerada uma indicação útil de contaminação pós-sanitização ou pós-processo (principalmente no caso da pasteurização), indicando falhas higiênicas ao longo do processamento e armazenamento do produto ou deficiência do tratamento térmico, já que não são organismos esporulados (Hajdenwurcel,1998), evidenciando também práticas de higiene e sanificação aquém dos padrões requeridos para o processamento de alimentos.

Os microrganismos pertencentes ao grupo dos coliformes fecais são bactérias com forma de bastonetes, Gram negativas, não esporuladas, anaeróbias facultativas, capazes de fermentar a lactose com produção de gás, em 24h a 44,5 - 45,5 C (Hajdenwurcel,1998). Esta definição objetivou, em princípio, selecionar apenas os coliformes originários do trato gastrintestinal. Atualmente sabe-se, entretanto, que o grupo dos coliformes fecais inclui pelo menos três gêneros Escherichia, Enterobacter e Klebsiella, dos quais dois (Enterobacter e Klebsiella) incluem cepas de origem não fecal (água, solo, vegetais). Por esse motivo, a presença de coliformes fecais em alimentos é menos representativa, como indicação de contaminação fecal, do que a enumeração de $E$. coli, porém muito mais significativa do que a presença de coliformes totais, dada a alta incidência de $E$. coli dentro do grupo fecal (Hajdenwurcel,1998; Silva et al., 1997).

Dentre as bactérias de habitat reconhecidamente fecal, E.coli é a mais conhecida e a mais facilmente diferenciada dos membros não fecais (Silva et al.,1997). Todos os demais membros do grupo tem uma associação duvidosa com a contaminação fecal e E. coli, embora também possa ser introduzida nos alimentos a partir de fontes não fecais, é o melhor indicador de contaminação fecal conhecido até o momento (Hajdenwurcel,1998). 
Molenda (1994) afirma que a E.coli é uma bactéria presente na microflora normal do trato intestinal de humanos e de animais de sangue quente, e está geralmente presente nas fezes. Os humanos são o seu principal reservatório. Os tipos enteropatogênico, enteroinvasivo e enterotoxigênico de E.coli são principalmente de origem fecal.

A situação difere quando se trata da E.coli O157:H7. O gado, parece ser o reservatório deste tipo de E.coli que pode ser encontrado no trato intestinal de vacas leiteiras. A carne pode ser contaminada durante $\mathrm{O}$ processamento, bem como o leite. Este tipo de E.coli é o mais largamente distribuído nos EUA. Eficientes tratamentos térmicos utilizados em alimentos de origem animal, como carnes e leite crus, para inativar o patógeno, são indispensáveis e obrigatórios (Cliver,1990).

Somente no final de 1992, ocorreu uma maior conscientização da população com relação a E.coli O157:H7, devido a um surto ocorrido numa grande rede de "fast food", pelo consumo de hamburgueres mal cozidos, envolvendo 600 pessoas e resultando na morte de 4 crianças (Silva et al.,1997).

São basicamente 4 tipos de E.coli que tem sido implicadas em surtos de doenças de origem alimentar. A primeira é a E.coli enteropatogênica (EPEC). Este microrganismo é notoriamente conhecido como a causa de surtos de diarréia neonatal que ocorrem freqüentemente em enfermarias. Esta bactéria é um sério problema em alguns países em desenvolvimento e foi o maior problema nos EUA na década de 40 e 50, mas deixou de ser nos últimos anos. Muitos adultos são portadores assintomáticos da doença.

Outro grupo de E.coli patogênica, é o das enteroinvasivas (EIEC). A EIEC tem um comportamento patológico muito semelhante à Shigella. Os sintomas são febre, dores abdominais e diarréia (Silva et al.,1997). Estudos com humanos voluntários têm demonstrado que a dose de infecção é alta, geralmente em torno de $10^{6}-10^{8}$ UFC. O período de incubação é de 8 a 24 
horas e a duração da doença é de vários dias. O curso da infecção é similar à shigellose (Cliver,1990). A bactéria invade as células epiteliais do intestino grosso, se multiplica e invade as células adjacentes, causando necrose no tecido epitelial do cólon e diarréia sanguinolenta (Silva et al.,1997).

A E.coli enterotoxigênica (ETEC), nos países em desenvolvimento está associada à diarréia conhecida como "diarréia dos viajantes" (Silva et al.,1997). Segundo Cliver (1990), os sintomas são similares aos da cólera - diarréia aquosa, desidratação, e às vezes, vômitos. O pouco que se sabe sobre a doença é resultado de estudos realizados em humanos voluntários, onde se observou que a dose de infecção está entre $10^{8}-10^{10}$ UFC (alta). O período de incubação é de $8-44$ horas e a duração da doença é curta, em torno de 24-30 horas.

O quarto tipo de E.coli é a O157:H7. Entre os grupos patogênicos de E.coli esta é, com certeza, a mais importante em termos de doenças de origem alimentar. Este tipo de E.coli é também conhecido como E.coli enterohemorrágica ou produtora de verotoxina (VTEC). Três principais síndromes têm sido associadas com E.coli 0157:H7. A primeira é a colite hemorrágica, que em casos mais graves resulta no quadro conhecido como (HUS) síndrome-urêmica hemolítica (segunda síndrome), e a terceira é chamada de (TTP), similar à HUS, mas que também envolve danos no cérebro, com taxa de mortalidade muito alta. No entanto, e felizmente, a freqüência é baixa (Cliver,1990).

A contaminação fecal dos alimentos, tanto por contato direto ou indiretamente por meio da água é o mais importante meio de transmissão. Este tipo de contaminação muito provavelmente afeta as carnes, os produtos cárneos e as verduras frescas, que se transformam assim em fontes de infecção. Pelo fato de E.coli estar sempre presente nas fezes, esta bactéria é freqüentemente usada como indicadora de contaminação fecal nos alimentos (Eley, 1994). 


\subsection{Staphylococcus aureus}

Os Staphylococcus são bactérias em forma de cocos (células esféricas), com cerca de 1 mícron de diâmetro, que se apresentam morfologicamente em massas irregulares, lembrando cachos de uva, não sendo raro, no entanto, o surgimento de elementos isolados, aos pares, cadeias curtas, e até em forma de tétrades.

Staphylococcus aureus é muito vulnerável a destruição por tratamento térmico e por quase todos os agentes sanitizantes (Bennett \& Lancette, 1995).

Apresentam a propriedade de serem Gram-positivos, aeróbios ou anaeróbios facultativos, crescerem bem a $37^{\circ} \mathrm{C}$, em um pH em torno de 7,0. Não produzem esporos, podem permanecer vivos durante semanas em refrigeração, mas são destruídos em 30 minutos a $60^{\circ} \mathrm{C}$ ou 1 minuto a $100^{\circ} \mathrm{C}$; são relativamente resistentes à dessecação e a uma concentração de $9 \%$ de cloreto de sódio; dentro do grupo das não esporuladas, são considerados uma das bactérias mais resistentes.

Segundo Vanderzant \& Splittstoesser (1992), o crescimento de $S$. aureus em alimentos representa um risco potencial a saúde pública pois existem cepas de $S$. aureus produtoras de enterotoxinas que causam envenenamento alimentar se ingeridas. Alimentos submetidos a contaminação por cepas de $S$. aureus produtoras de enterotoxinas após o processamento apresentam um risco significativo devido a ausência de organismos competidores que em condições normais restringem o crescimento de $S$. aureus e a produção de enterotoxinas.

Alimentos normalmente associados com envenenamento alimentar por $S$. aureus são carnes e produtos cárneos, saladas, produtos de padaria (com creme) e produtos lácteos. Muitos desses produtos são contaminados durante o preparo em casa ou em estabelecimentos alimentares. Em alimentos processados a contaminação pode ser de origem humana, de 
animais ou do meio ambiente. Essa contaminação pode ser através da pele, boca ou nariz dos manipuladores. No entanto, as chances de haver produção de toxinas são maiores em alimentos expostos a temperaturas que permitem o crescimento de $S$. aureus.

A presença significante de $S$. aureus em alimentos deve ser interpretada cuidadosamente. A capacidade de certas linhagens de produzirem enterotoxinas é notada em condições que permitem o crescimento e um grande número de $S$. aureus estará presente, normalmente acima de $10^{6} \mathrm{UFC} / \mathrm{g}$. Porém, alimentos com grandes números desse microrganismo não podem ser incriminados como vetor de um envenenamento alimentar, a menos que toxinas sejam detectadas nos mesmos.

O homem, o bovino e o cão podem ser reservatórios do Staphylococcus, pois o mesmo é residente da nasofaringe, boca, trato intestinal e diversas áreas da pele, comumente caracterizando-se como portadores assintomáticos. O microrganismo é responsável por diversas patogenias, de importância clínica e epidemiológica (Guerreiro et al., 1984).

O envenenamento alimentar por $S$. aureus ocorre pela ingestão da enterotoxina produzida por certas linhagens (Lavoie et al., 1997). A enterotoxina A é uma das principais enterotoxinas produzidas por $S$. aureus podendo causar surtos de origem alimentar ( Tsen et al, 1998). Segundo Lavoie et al. (1997) esta enterotoxina é a causa de $80 \%$ das intoxicações estafilocócicas.

As intoxicações alimentares produzidas por enterotoxinas se caracterizam pelos seguintes sintomas: incubação rápida de 1 a 3 horas, em média, náuseas, vômitos, vertigens, diarréia e frequentemente, choque, que às vezes leva à morte (Guerreiro et al., 1984).

Segundo Eley (1994), o tipo de intoxicação alimentar se caracteriza pelo aparecimento de náuseas, vômitos, dor abdominal e prostação, sem febre, aproximadamente 1 - 6 horas depois da ingestão do alimento contaminado. Entretanto a maioria dos pacientes se recupera dentro de 24 
horas sem a necessidade de uma terapia específica e apresenta uma taxa de mortalidade baixa.

Cliver (1990), descreve as enterotoxinas estafilocócicas como proteínas de cadeia simples, com peso molecular de 26.000 - 29.000 D. São basicamente proteínas com ponto isoelétrico entre 7.0 - 8.6. São resistentes à enzimas proteolíticas, como pepsina e tripsina, o que torna possível sua passagem pelo trato digestivo. As enterotoxinas são relativamente estáveis ao calor, sendo necessários 30 minutos a $100^{\circ} \mathrm{C}$ para sua destruição.

Para a detecção da enterotoxina termoestável, são necessárias concentrações de $10^{5}$ a $10^{6} \mathrm{UFC} / \mathrm{g}^{1}$ de alimentos. Entretanto, altas concentrações de $S$. aureus não indicam, necessariamente, a presença de enterotoxinas (Pazakova et al., 1997).

Já Eley (1996) afirma que as toxinas estafilocócicas não podem ser consideradas enterotoxinas clássicas, pois não atuam diretamente nas células do intestino e sim em receptores no intestino, com os estímulos atingindo o sistema nervoso central, provocando vômitos, podendo por isso ser considerada uma neurotoxina.

S. aureus pode produzir uma variedade de proteínas extracelulares que contribuem para a patogenicidade do microrganismo. Certas cepas de $S$. aureus produzem enterotoxinas $\left(A, B, C_{1}, C_{2}, C_{3}, D\right.$ e $\left.E\right)$ que podem causar envenenamentos esporádicos ou surtos (Eley, 1996; Tsen et al., 1998).

Dentre os vários casos de intoxicação estafilocócica por carnes contaminadas, um caso relatado no Mississippi estava relacionado ao consumo de carne suína, durante um jantar em clube cívico, em uma pequena cidade do Estado. Imediatamente após o jantar, desenvolveram-se os sintomas da intoxicação - náuseas e vômitos. A amostra de carne suína apresentou alta contaminação por $S$. aureus. Uma investigação mostrou que a carne havia sido exposta a temperaturas inadequadas para sua conservação por várias horas. 
De acordo com o Centro de Controle de Doenças de Origem Alimentar de 1981, das doenças causadas por bactérias, 17,6\% (44 surtos) foram envenenamento alimentar por S. aureus. Outros 137 surtos apresentaram sintomas parecidos, mas não haviam evidências suficientes para reportá-las (Cliver, 1990).

\subsection{Clostridium}

De acordo com Franco \& Landgraf (1996) as espécies de bactérias do gênero Clostridium são, com exceção de algumas aerotolerantes, anaeróbias estritas e catalase negativas, não apresentando desenvolvimento em ambientes aeróbios. A principal fonte de clostrídios é o solo, podendo ser encontrados também no trato intestinal do homem e de animais. Podem ser mesófilas ou termófilas, proteolíticas ou não proteolíticas. Entre as espécies mesófilas proteolíticas responsáveis pela putrefação em diversos tipos de alimentos encontram-se: C. lentoputrecens, C. putrefaciens, C. pausteurianum e C. sporogenes. C. perfringens e C. botulinum são espécies produtoras de toxinas causadoras de intoxicação alimentar quando ingeridas (Frazier \& Westhoff, 1993).

O Clostridium perfringes tem sido associado com gastroenterites desde 1895. A enterotoxina responsável pela intoxicação alimentar é uma proteína que pode ser produzida pelo $C$. perfringens no trato intestinal do doente ou, em alguns casos, no próprio alimento (Jay, 1998; Ray, 1996).

De acordo com Franco \& Landgraf (1996) esse microrganismo

é responsável por dois tipos diferentes de intoxicação alimentar. Cepas do tipo A causam infecção alimentar na forma clássica e as do tipo $C$ causam a enterite necrótica, bem mais grave.

A enterite necrótica, causada por $C$. perfringens do tipo $C$ causa dores abdominais muito intensas, diarréia sangüinolenta, algumas vezes 
vômitos, e inflamação necrótica do intestino delgado, sendo freqüentemente fatal. Os casos da doença são raros, mas geralmente associados ao consumo de carne de porco mal cozida (Franco \& Landgraf, 1996). Os sintomas da intoxicação alimentar por C. perfringens do tipo A aparecem rapidamente, entre 6 - 24 hs após a ingestão do alimento contaminado. Os sintomas são fortes dores abdominais e diarréia. O período de duração da doença também é curto, cerca de um dia. Geralmente os alimentos envolvidos são carnes preparadas na véspera do consumo (Jay, 1998). A intoxicação é causada pela ingestão de um grande número de células viáveis $\left(5,0 \times 10^{5} / \mathrm{g}\right.$ de alimento) (Ray, 1996).

Quando a análise de clostridium sulfito-redutores a $46^{\circ} \mathrm{C}$ é realizada, um dos alvos bacterianos para detecção é o Clostridium perfringens.

O termo botulismo, utilizado para designar a intoxicação provocada pela toxina do $C$. botulinum, provém de botulus, que em latim significa salsicha, devido ao envolvimento deste alimento nos primeiros casos de botulismo cientificamente comprovados (Franco \& Landgraf, 1996).

Os sintomas do botulismo de origem alimentar desenvolvemse entre 12 e $72 \mathrm{~h}$ após a ingestão do alimento contaminado pela toxina. A princípio são desenvolvidos sintomas gastrintestinais (náuseas, vômito, diarréia) seguidos por sintomas neurológicos como visão dupla, paralisia muscular, parada respiratória e morte. A duração dos sintomas é de 1 a 10 dias e as taxas de mortalidade variam entre 30 e $65 \%$ (Jay, 1998). É necessário apenas uma pequena quantidade da toxina para a intoxicação (1ng/Kg de peso) (Ray, 1996).

Os alimentos mais comumente associados ao botulismo são as frutas e hortaliças, enlatados e peixes. Carnes e derivados apresentam menor ocorrência provavelmente pelo fato de sofrerem tratamento térmico e serem consumidos rapidamente (Ray, 1996). 


\subsection{Mesófilos e Psicrotróficos totais}

A temperatura é um fator muito importante na velocidade de crescimento de uma população de microrganismos. O maior crescimento microbiano se dá na sua temperatura ótima de crescimento, variando entre as espécies (Hayes, 1993).

De acordo com Bourgeois et al. (1994) os microrganismos mesófilos são aqueles que apresentam crescimento em temperaturas entre 20 $45^{\circ} \mathrm{C}$, com temperatura ótima em torno de $37^{\circ} \mathrm{C}$. Os principais gêneros e espécies de bactérias patógenas ao homem desenvolvem-se nesta faixa de temperatura.

Já os microrganismos psicrotróficos são aqueles que desenvolvem-se na faixa de $0-35^{\circ} \mathrm{C}$, sendo a temperatura ótima entre $20-30^{\circ} \mathrm{C}$. Estes microrganismos desenvolvem-se em temperaturas de refrigeração, mas são pouco resistentes ao calor (Frazier \& Westhoff, 1993; Hayes, 1993). No entanto esta definição não é muito clara podendo variar conforme o autor. Para Ray (1996) a faixa de crescimento dos psicrófilos está entre -5 e $20^{\circ} \mathrm{C}$, com ótimo a $15^{\circ} \mathrm{C}$ e para Franco \& Landgraf (1996) a faixa de crescimento está entre 0 e $20^{\circ} \mathrm{C}$, com ótimo entre 10 e $15^{\circ} \mathrm{C}$.

De acordo com Bourgeois et al. (1994) os psicrófilos podem ser encontrados em todos os tipos de alimentos refrigerados, como carnes, pescados e legumes. Os principais gêneros são: Pseudomonas, Alcaligenes, Erwinia, Corynebacterium, Flavobacterium, Lactobacillus e Streptomyces.

Segundo Jay (1998) os psicrófilos ocorrem apenas em oceanos ou climas extremamente frios. Os microrganismos responsáveis pela deterioração de produtos estocados sob temperatura de refrigeração são chamados psicrotróficos. Os psicrotróficos são mesófilos capazes de produzir colônias visíveis, à uma temperatura de $0^{\circ}$ a $7^{\circ} \mathrm{C}$, no intervalo de 7 a 10 dias. 


\section{MATERIAL E MÉTODOS}

\subsection{Meios de Cultivo Utilizados}

\subsection{1 Ágar Padrão para Contagem (PCA) - Difco (0479)}

É um meio muito utilizado nas análises microbiológicas de alimentos para contagem total de microrganismos mesófilos, psicrófilos ou termófilos.

\begin{tabular}{|lr|}
\hline Componentes & Quantidades \\
- Triptona & $5,0 \mathrm{~g}$ \\
- Extrato de levedura & $2,5 \mathrm{~g}$ \\
- Dextrose & $1,0 \mathrm{~g}$ \\
- Ágar & $15,0 \mathrm{~g}$ \\
- Água destilada & $1.000 \mathrm{~mL}$ \\
\hline
\end{tabular}

Quadro 1 - Composição do meio PCA em componentes/litro de meio'.

Fonte: Difco (1984)

${ }^{1} \mathrm{pH}$ final $7,0 \pm 0,2 \mathrm{a} 25^{\circ} \mathrm{C}$.

\subsubsection{Caldo Lauril Sulfato Triptose (LST) - Difco (0241)}

É um meio utilizado para detectar microrganismos fermentadores de lactose em água e alimentos. A formação de gás através da fermentação da lactose indica a possível presença de bactérias do grupo coliforme. É um teste presuntivo, sendo necessária a confirmação através de meios seletivos para o crescimento de coliformes. 


\begin{tabular}{|lr|}
\hline Componentes & Quantidades \\
\hline - Triptose & $20 \mathrm{~g}$ \\
- Lactose & $5 \mathrm{~g}$ \\
- Fosfato dipotássico & $2,75 \mathrm{~g}$ \\
- Fosfato monopotássico & $2,75 \mathrm{~g}$ \\
- Cloreto de sódio & $5 \mathrm{~g}$ \\
- Lauril Sulfato & $0,1 \mathrm{~g}$ \\
- Água destilada & $1.000 \mathrm{~mL}$ \\
\hline
\end{tabular}

Quadro 2 - Composição do Caldo LST em componentes/litro de meio ${ }^{1}$.

Fonte: Difco (1984)

${ }^{1} \mathrm{pH}$ final $6,8 \pm 0,2 \mathrm{a} 25^{\circ} \mathrm{C}$.

\subsubsection{Caldo Verde Brilhante Lactose Bile 2\% (CVBLB) - Difco (0007)}

É um meio utilizado para confirmar a presença de bactérias do grupo coliforme, através de produção de gás pela fermentação da lactose.

\begin{tabular}{|lr|}
\hline Componentes & Quantidades \\
\hline - Peptona & $10,0 \mathrm{~g}$ \\
- Oxgall & $20,0 \mathrm{~g}$ \\
- Lactose & $10,0 \mathrm{~g}$ \\
- Verde brilhante & $0,0133 \mathrm{~g}$ \\
Água destilada & $1.000 \mathrm{~mL}$ \\
\hline
\end{tabular}

Quadro 3 - Composição do caldo verde brilhante lactose bile (CVBLB) em componentes/litro ${ }^{1}$.

Fonte: Difco (1984)

${ }^{1} \mathrm{pH}$ final $7,2 \pm 0,2 \mathrm{a} 25^{\circ} \mathrm{C}$. 


\subsubsection{Caldo E. coli (EC) - Difco (0314)}

É um meio utilizado para a confirmação de coliformes fecais em água e alimentos.

\begin{tabular}{|lr|}
\hline Componentes & Quantidades \\
\hline - Triptose & $20,0 \mathrm{~g}$ \\
- Lactose & $5,0 \mathrm{~g}$ \\
- Sais biliares & $1,5 \mathrm{~g}$ \\
- Fosfato dipotássico $\left(\mathrm{K}_{2} \mathrm{HPO}_{4}\right)$ & $4,0 \mathrm{~g}$ \\
- Fosfato monopotássico $\left(\mathrm{KH}_{2} \mathrm{PO}_{4}\right)$ & $1,5 \mathrm{~g}$ \\
- Cloreto de sódio $(\mathrm{NaCl})$ & $5,0 \mathrm{~g}$ \\
- Água destilada & $1.000 \mathrm{~mL}$ \\
\hline
\end{tabular}

Quadro 4 - Composição do caldo EC em componentes / litro'.

Fonte: Difco (1984)

${ }^{1} \mathrm{pH}$ final $6,9 \pm 0,2 \mathrm{a} 25^{\circ} \mathrm{C}$.

\subsection{4 Ágar Baird-Parker (BPA) - Difco (0768)}

É utilizado para a detecção e enumeração de Staphylococcus em alimentos. Este meio contém cloreto de lítio e telurito de potássio, que inibem o crescimento de outros microrganismos, e piruvato e glicina, que estimulam o crescimento de Staphylococcus. O telurito e a emulsão de ovo proporcionam a diferenciação das colônias de Staphylococcus pela formação de colônias pretas, brilhantes, convexas e com halo de hidrólise da lectina. 


\begin{tabular}{|lr|}
\hline Componentes & Quantidades \\
\hline - Triptona & $10 \mathrm{~g}$ \\
- Extrato de carne & $5 \mathrm{~g}$ \\
- Extrato de levedura & $1 \mathrm{~g}$ \\
- Glicina & $12 \mathrm{~g}$ \\
- Piruvato de sódio & $10 \mathrm{~g}$ \\
- Cloreto de lítio & $5 \mathrm{~g}$ \\
- Ágar & $20 \mathrm{~g}$ \\
- Água destilada & $1.000 \mathrm{~mL}$ \\
\hline
\end{tabular}

Quadro 5 - Composição do meio BPA em componentes/litro de meio'.

Fonte: Difco (1984)

${ }^{1} \mathrm{pH}$ final $7,0 \pm 0,2$ a $25^{\circ} \mathrm{C}$.

\subsubsection{Sulfito-Polimixina-Sulfadiazina-Agar (SPS-A) - Difco (0845)}

É um meio seletivo e diferencial para a detecção e enumeração de Clostridium sulfito-redutores em alimentos. Os Clostridium sulfito-redutores reduzem o sulfito à sulfeto, que se combina com o ferro do meio formando sulfeto de ferro (FeS) fazendo com que a colônia fique preta. A polimixina e a sulfadiazina inibem o crescimento de outros microrganismos sulfito-redutores. 


\begin{tabular}{|lr|}
\hline Componentes & Quantidades \\
\hline - Peptona de caseína & $15 \mathrm{~g}$ \\
- Extrato de levedura & $10 \mathrm{~g}$ \\
- Citrato de ferro & $0,5 \mathrm{~g}$ \\
- Sulfito de sódio & $0,5 \mathrm{~g}$ \\
- Sulfadiazina sódica & $0,12 \mathrm{~g}$ \\
- Sulfato de Polimixina B & $0,01 \mathrm{~g}$ \\
- Ágar & $4 \mathrm{~g}$ \\
- Água destilada & $1.000 \mathrm{~mL}$ \\
\hline
\end{tabular}

Quadro 6 - Composição do meio SPS-A em componentes/litro de meio'.

Fonte: Difco (1984)

${ }^{1} \mathrm{pH}$ final $7,0 \pm 0,2$ a $25^{\circ} \mathrm{C}$.

\subsection{6 Água peptonada $0,1 \%\left(\mathrm{H}_{2} \mathrm{Op}\right)$ - Diagnolab (713495)}

É utilizada como diluente e para homogeinizar as amostras para a análise.

\begin{tabular}{|lr|}
\hline Componentes & Quantidades \\
\hline - Peptona & $1,0 \mathrm{~g}$ \\
- Água destilada & $1.000 \mathrm{~mL}$ \\
\hline
\end{tabular}

Quadro 7 - Composição da solução de água peptonada 0,1\% em componentes/ litro ${ }^{1}$.

Fonte: Diagnolab

${ }^{1} \mathrm{pH}$ final 7,0 . 


\subsubsection{Kit "Oxoid Salmonella Rapid Test" e seus meios}

- Água peptonada tamponada - BPW (Oxoid - CM509): utilizada como meio de pré-enriquecimento para a detecção de Salmonella.

\begin{tabular}{|lr|}
\hline Componentes & Quantidades \\
\hline - Peptona & $10,0 \mathrm{~g}$ \\
- Cloreto de sódio $(\mathrm{NaCl})$ & $5,0 \mathrm{~g}$ \\
- Fosfato dipotássico $\left(\mathrm{K}_{2} \mathrm{HPO}_{4}\right)$ & $3,5 \mathrm{~g}$ \\
- Fosfato monopotássico $\left(\mathrm{KH}_{2} \mathrm{PO}_{4}\right)$ & $1,5 \mathrm{~g}$ \\
- Água destilada & $1.000 \mathrm{~mL}$ \\
\hline
\end{tabular}

Quadro 8 - Composição da BPW em componentes / litro1.

Fonte: Oxoid

${ }^{1} \mathrm{pH}$ final $7,2 \pm 0,2$.

- Meio Salmonella Rapid Test Elective Medium (SRTEM) - Oxoid CM857: meio seletivo para Salmonella.

\begin{tabular}{|lr|}
\hline Componentes & Quantidades \\
\hline - Triptona & $10,0 \mathrm{~g}$ \\
- Cloreto de sódio $(\mathrm{NaCl})$ & $5,0 \mathrm{~g}$ \\
- Fosfato dissódico $\left(\mathrm{Na}_{2} \mathrm{HPO}_{4}\right)$ & $9,0 \mathrm{~g}$ \\
- Fosfato monopotássico $\left(\mathrm{KH}_{2} \mathrm{PO}_{4}\right)$ & $1,5 \mathrm{~g}$ \\
- Caseína & $5,0 \mathrm{~g}$ \\
- Verde malaquita & $0,0025 \mathrm{~g}$ \\
- Água destilada & $1.000 \mathrm{~mL}$ \\
\hline
\end{tabular}

Quadro 9 - Composição do meio SRTEM em componentes / litro.

Fonte: Oxoid

${ }^{1} \mathrm{pH}$ final $7,2 \pm 0,2$. 


\subsubsection{Equipamentos e vidraria tradicionalmente utilizados em laboratório de microbiologia.}

\subsection{Obtenção das carnes}

As carnes de capivara, cateto e javali foram obtidas, na forma congelada, em açougue de carnes silvestres no município de São Paulo. As carnes foram transportadas em caixa isotérmica, sob gelo para preservação do estado original das mesmas. Foram analisadas 9 amostras para cada tipo de carne, com 3 repetições analíticas para cada uma delas, num total de 27 análises para cada produto. As carnes foram descongeladas sob refrigeração para preservar ao máximo suas condições originais.

\subsection{Preparo das amostras}

Antes de dar início as análises propriamente ditas, as amostras foram submetidas a um preparo prévio.

Retirou-se de cada amostra de carne 50 gramas para serem triturados em liquidificador, em copo previamente esterilizado, adicionando-se $450 \mathrm{~mL}$ de diluente (água peptonada esterilizada $0,1 \%$ ), obtendo-se assim a diluição $10^{-1}$. As amostras não foram expostas a mais de 3 minutos de desintegração mecânica para evitar um excessivo aquecimento das mesmas.

Transferindo-se $10 \mathrm{ml}$ da diluição $10^{-1}$ para $90 \mathrm{ml}$ de água peptonada esterilizada $0,1 \%$, obteve-se a diluição $10^{-2}$ e assim sucessivamente até obter todas as diluições necessárias aos diversos plaqueamentos (Fiigura 1).

As diluições foram selecionadas em função do nível estimado de contaminação, de forma a serem obtidas placas com 30 a 300 unidades formadoras de colônias (UFC).

A determinação de Salmonella dispensou o uso de diluições, uma vez que esta bactéria não pode estar presente em $25 \mathrm{~g}$ de qualquer produto 
destinado ao consumo humano. Para esta análise foi feito um préenriquecimento de cada amostra a ser analisada, triturando em liquidificador, com copo previamente esterilizado, $25 \mathrm{~g}$ de carne em $225 \mathrm{~mL}$ de água peptonada tamponada esterilizada.

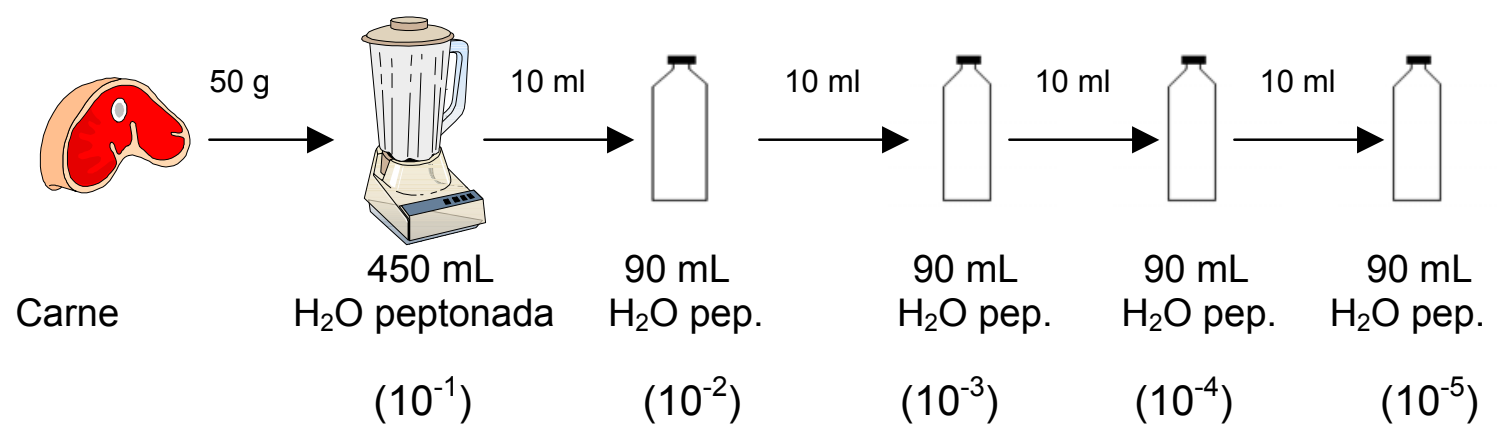

Figura 1 - Procedimento para o preparo das diluições.

\subsection{Análises microbiológicas}

As amostras foram analisadas através das metodologias tradicionais de acordo com as normas descritas pela Associação Brasileira de Normas Técnicas (ABNT, 1991) e por Vanderzant \& Splittstoesser (1992).

Para a detecção de Salmonella, utilizou-se o kit "Salmonella Rapid Test", da Oxoid (FT 201A, com aprovação pela AOAC, número de licença 960902, de 1993).

\subsubsection{Contagem total de aeróbios mesófilos e psicrotróficos}

Para a contagem total de aeróbios mesófilos e psicrotróficos foi utilizado o método de plaqueamento em profundidade. Após serem feitas as diluições foram retiradas alíquotas de $1 \mathrm{ml}$ e inoculadas em placas de Petri previamente esterilizadas. Em cada placa inoculada foi adicionado de 15 a $20 \mathrm{ml}$ do meio Plate Count Agar (PCA), previamente fundido e resfriado até a temperatura de 
$45^{\circ} \mathrm{C}$. O inóculo foi misturado ao meio de cultura através de movimentos circulares suaves e em movimentos na forma de oito. Após a completa solidificação do meio as placas foram invertidas e incubadas a $35^{\circ} \mathrm{C}$ por 48 horas, para contagem de mesófilos e a $7^{\circ} \mathrm{C}$ por 10 dias, para a contagem de psicrotróficos (Figura 2). Para a contagem das colônias foram selecionadas as placas que continham entre 30 e 300 colônias. A contagem foi feita com o auxílio de uma lupa, em um contador de colônias tipo Quebec. Todas as análises foram feitas em triplicatas e obtida a média aritmética das contagens das UFC.

Os resultados obtidos foram comparados com os padrões vigentes no país para outros tipos de carnes, utilizadas para consumo humano, uma vez que não existem padrões específicos para carnes de animais silvestres.

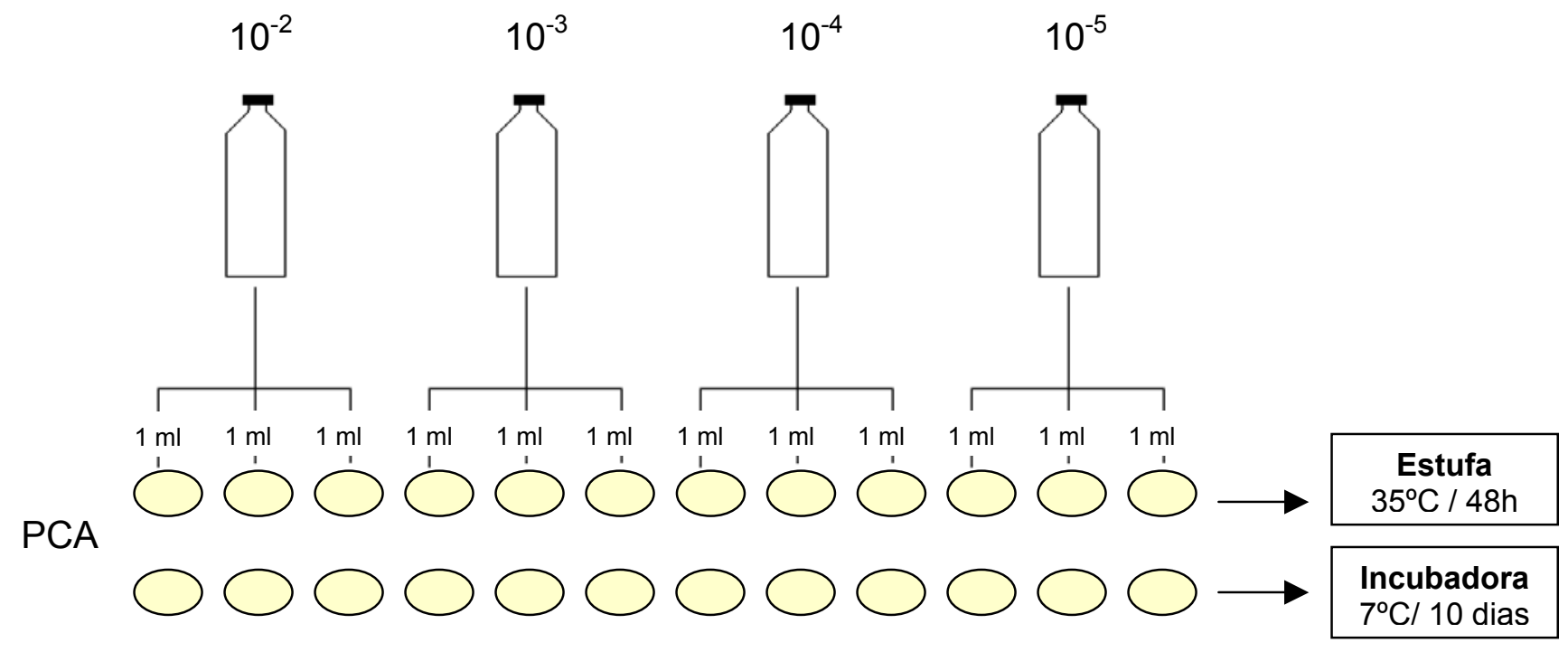

Figura 2 - Procedimento para contagem total de mesófilos e psicrotróficos. 


\subsubsection{Número mais provável (NMP) de coliformes totais e fecais}

O Número Mais Provável (NMP) de coliformes totais e coliformes fecais foi determinado através da técnica dos Tubos Múltiplos. Esta técnica permite a recuperação de células injuriadas através de um enriquecimento.

A análise compreende duas fases distintas: a fase do teste presuntivo e a fase do teste confirmativo.

No teste presuntivo foram utilizadas três séries de tubos de ensaio contendo tubos de Durham e Caldo Lauril Sulfato Triptose (LST).

A primeira série de tubos continha dupla concentração do Caldo LST e recebeu $10 \mathrm{~mL}$ do inóculo da diluição $10^{-1}$. As duas séries seguintes, que continham Caldo LST em concentração normal, receberam respectivamente $1 \mathrm{~mL}$ das diluições $10^{-1}$ e $10^{-2}$. As três séries de tubos foram incubadas a $35^{\circ} \mathrm{C}$ por 24 - 48 horas. Após o período de incubação, os tubos que apresentaram produção de gás devido a fermentação da lactose do meio, evidenciada pela formação de bolhas no tubo de Durham, foram considerados positivos no teste presuntivo. Os tubos que após 48 horas não apresentaram nenhuma alteração no tubos de Durham, foram considerados negativos.

Com o auxílio da alça níquel-cromo foram retiradas alíquotas dos tubos positivos e transferidas para tubos contendo Caldo Verde Brilhante Bile(CVBLB) $2 \%$, e para tubos contendo Caldo E. coli (EC).

Esta segunda fase é denominada de teste confirmativo. O CVBLB $2 \%$ é bastante seletivo devido a presença de verde brilhante e sais biliares e inibe $o$ crescimento de microrganismos Gram positivos. A lactose presente no meio é fermentada pelos coliformes o que resulta na formação de gás.

Os tubos contendo CVBLB $2 \%$ e o inóculo foram incubados a $35^{\circ} \mathrm{C}$ por 24 - 48 horas. O tubos que apresentaram formação de gás confirmaram o teste presuntivo. Estes tubos foram considerados positivos para coliformes totais, podendo ser de origem fecal ou não.

Os tubos contendo Caldo EC foram utilizados para a detecção de coliformes de origem fecal. O Caldo EC é seletivo devido a presença de sais 
biliares e também apresenta a lactose como único carboidrato. A temperatura e o período de incubação $\left(44,5^{\circ} \mathrm{C}\right.$ por 24 horas) impede que outros microrganismos fermentem a lactose, desse modo, se houver produção de gás fica clara a presença de coliformes fecais (Figura 3).

A partir dos números de tubos positivos de cada uma das três séries de ambos os meios (CVBLB 2\% e Caldo EC) é possível determinar o NMP de coliformes totais e fecais por grama de carne, através de Tabela própria da ABNT (Tabela 1).

Os resultados obtidos foram comparados com os padrões vigentes no país para outros tipos de carnes, utilizadas para consumo humano, uma vez que não existem padrões específicos para carnes de animais silvestres.

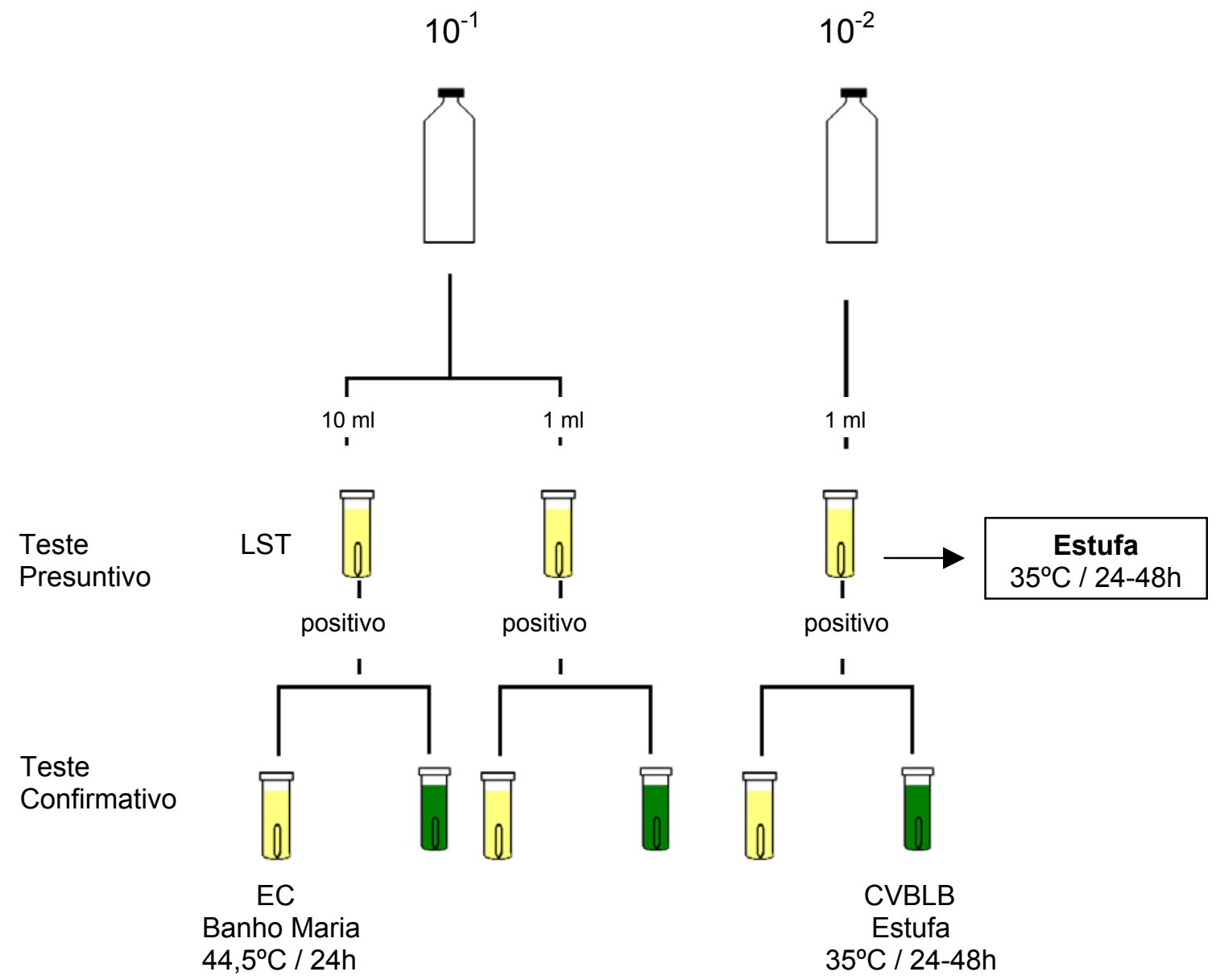

Figura 3 - Procedimento para a estimativa do NMP de coliformes totais e fecais. 
Tabela 1. Número mais provável para várias combinações de resultados positivos, quando três tubos são utilizados por diluição (inoculações de 1, 0,1 e 0,01 g ou mL da amostra).

\begin{tabular}{|c|c|c|c|c|c|c|c|}
\hline \multicolumn{4}{|c|}{ Combinação de tubos positivos } & \multicolumn{4}{|c|}{ Combinação de tubos positivos } \\
\hline $1,0 \mathrm{~g}-\mathrm{mL}$ & $0,1 \mathrm{~g}-\mathrm{mL}$ & $0,01 \mathrm{~g}-\mathrm{mL}$ & NMP & $1,0 \mathrm{~g}-\mathrm{mL}$ & $0,1 \mathrm{~g}-\mathrm{mL}$ & $0,01 \mathrm{~g}-\mathrm{mL}$ & NMP \\
\hline 0 & 0 & 0 & $<0,3$ & 2 & 0 & 0 & 0,91 \\
\hline 0 & 0 & 1 & 0,3 & 2 & 0 & 1 & 1,4 \\
\hline 0 & 0 & 2 & 0,6 & 2 & 0 & 2 & 2,0 \\
\hline 0 & 0 & 3 & 0,9 & 2 & 0 & 3 & 2,6 \\
\hline 0 & 1 & 0 & 0,3 & 2 & 1 & 0 & 1,5 \\
\hline 0 & 1 & 1 & 0,61 & 2 & 1 & 1 & 2,0 \\
\hline 0 & 1 & 2 & 0,92 & 2 & 1 & 2 & 2,7 \\
\hline 0 & 1 & 3 & 1,2 & 2 & 1 & 3 & 3,4 \\
\hline 0 & 2 & 0 & 0,62 & 2 & 2 & 0 & 2,1 \\
\hline 0 & 2 & 1 & 0,93 & 2 & 2 & 1 & 2,8 \\
\hline 0 & 2 & 2 & 1,2 & 2 & 2 & 2 & 3,5 \\
\hline 0 & 2 & 3 & 1,6 & 2 & 2 & 3 & 4,2 \\
\hline 0 & 3 & 0 & 0,94 & 2 & 3 & 0 & 2,9 \\
\hline 0 & 3 & 1 & 1,3 & 2 & 3 & 1 & 3,6 \\
\hline 0 & 3 & 2 & 1,6 & 2 & 3 & 2 & 4,4 \\
\hline 0 & 3 & 3 & 1,9 & 2 & 3 & 3 & 5,3 \\
\hline 1 & 0 & 0 & 0,36 & 3 & 0 & 0 & 2,3 \\
\hline 1 & 0 & 1 & 0,72 & 3 & 0 & 1 & 3,9 \\
\hline 1 & 0 & 2 & 1,1 & 3 & 0 & 2 & 6,4 \\
\hline 1 & 0 & 3 & 1,5 & 3 & 0 & 3 & 9,5 \\
\hline 1 & 1 & 0 & 0,73 & 3 & 1 & 0 & 4,3 \\
\hline 1 & 1 & 1 & 1,1 & 3 & 1 & 1 & 7,5 \\
\hline 1 & 1 & 2 & 1,5 & 3 & 1 & 2 & 12 \\
\hline 1 & 1 & 3 & 1,9 & 3 & 1 & 3 & 16 \\
\hline 1 & 2 & 0 & 1,1 & 3 & 2 & 0 & 9,3 \\
\hline 1 & 2 & 1 & 1,5 & 3 & 2 & 1 & 15 \\
\hline 1 & 2 & 2 & 2,0 & 3 & 2 & 2 & 21 \\
\hline 1 & 2 & 3 & 2,4 & 3 & 2 & 3 & 29 \\
\hline 1 & 3 & 0 & 1,6 & 3 & 3 & 0 & 24 \\
\hline 1 & 3 & 1 & 2,0 & 3 & 3 & 1 & 46 \\
\hline 1 & 3 & 2 & 2,4 & 3 & 3 & 2 & 110 \\
\hline 1 & 3 & 3 & 2,9 & 3 & 3 & 3 & $>110$ \\
\hline
\end{tabular}

Fonte: ABNT (1991) 


\subsubsection{Presença/Ausência de Salmonella}

Para a detecção de Salmonella spp na carne, utilizou-se o teste rápido OXOID Salmonella RAPID TEST (Unipath Ltda, 1999), oficializado pela Association of Official Analytical Chemists / Food and Drug Administration (AOAC/FDA) em 1993. É um teste extremamente sensível e apresenta alta taxa de concordância com o método tradicional. Outra vantagem do método é que dispensa qualquer equipamento para leitura. A principal desvantagem é que não detecta linhagens de Salmonella imóveis (Silva et al., 1997), embora cerca de $99 \%$ das cepas de Salmonella apresentem motilidade.

Para facilitar a detecção de Salmonella na análise é feito um préenriquecimento da amostra, para uma possível multiplicação ou recuperação de células injuriadas. Inoculou-se $25 \mathrm{~g}$ de carne em $225 \mathrm{ml}$ de água peptonada tamponada esterilizada e triturou-se em liquidificador previamente esterilizado. Incubou-se em estufa a $35^{\circ} \mathrm{C}$ por 24 horas.

Após o período de incubação, fez-se o preparo dos kits, que correspondem a frascos contendo dois tubos, A e B, ilustrados na Figura 4.

Cada um dos tubos contém dois meios separados por uma membrana porosa. Na parte inferior do tubo A encontra-se o meio Rappaport-Vassiliadis (modificado) que é um meio seletivo com alta pressão osmótica (cloreto de magnésio), baixo $\mathrm{pH}(5,2)$ e presença de verde malaquita. A Salmonella cresce muito bem nesse meio, sendo a flora acompanhante inibida. Na parte superior deste tubo encontra-se o meio Lisina Ferro Cistina Vermelho Neutro que é um meio indicador. A Salmonella possui a enzima cistina desulfohidrase, que quebra a cistina liberando $\mathrm{H}_{2} \mathrm{~S}$. $\mathrm{O}_{2} \mathrm{~S}$ liberado reage com o ferro do meio causando o enegrecimento da solução.

$\mathrm{Na}$ parte inferior do tubo B está o meio Lisina Ferro Desoxicolato (modificado) que é um meio seletivo e diferencial. $O$ desoxicolato age como inibidor de outras bactérias produtoras de $\mathrm{H}_{2} \mathrm{~S}$, que poderiam causar $\mathrm{O}$ enegrecimento da solução. Na parte superior do tubo B encontra-se o meio 
Verde Brilhante. A Salmonella não fermenta a lactose presente no meio, utilizando as peptonas como fonte de energia, liberando substâncias alcalinas, que aumentam o $\mathrm{pH}$ do meio. $\mathrm{O}$ indicador de $\mathrm{pH}$ vermelho de fenol presente no meio torna a solução vermelha em condições alcalinas.

Os meios contidos nos tubos $\mathrm{A}$ e $\mathrm{B}$ foram hidratados com água destilada esterilizada. Adicionou-se ao frasco externo aos tubos o meio seletivo para Salmonella SRTEM e um disco de antibiótico Novobiocina, para inibir o crescimento de outras bactérias. Adicionou-se ao frasco $1 \mathrm{ml}$ da amostra préenriquecida e incubou-se o kit a $41^{\circ} \mathrm{C}$, própria para o crescimento de Salmonella, por 24 horas. Após o período de incubação foi feita a leitura, de acordo com as colorações dos tubos A e B.

Como para qualquer método rápido de análise microbiológica, quando resultados positivos foram obtidos, os mesmos foram considerados testes presuntivos e foram confirmados através de prova sorológica pelo Salmonella Latex Test (FT 203A) da Oxoid. 

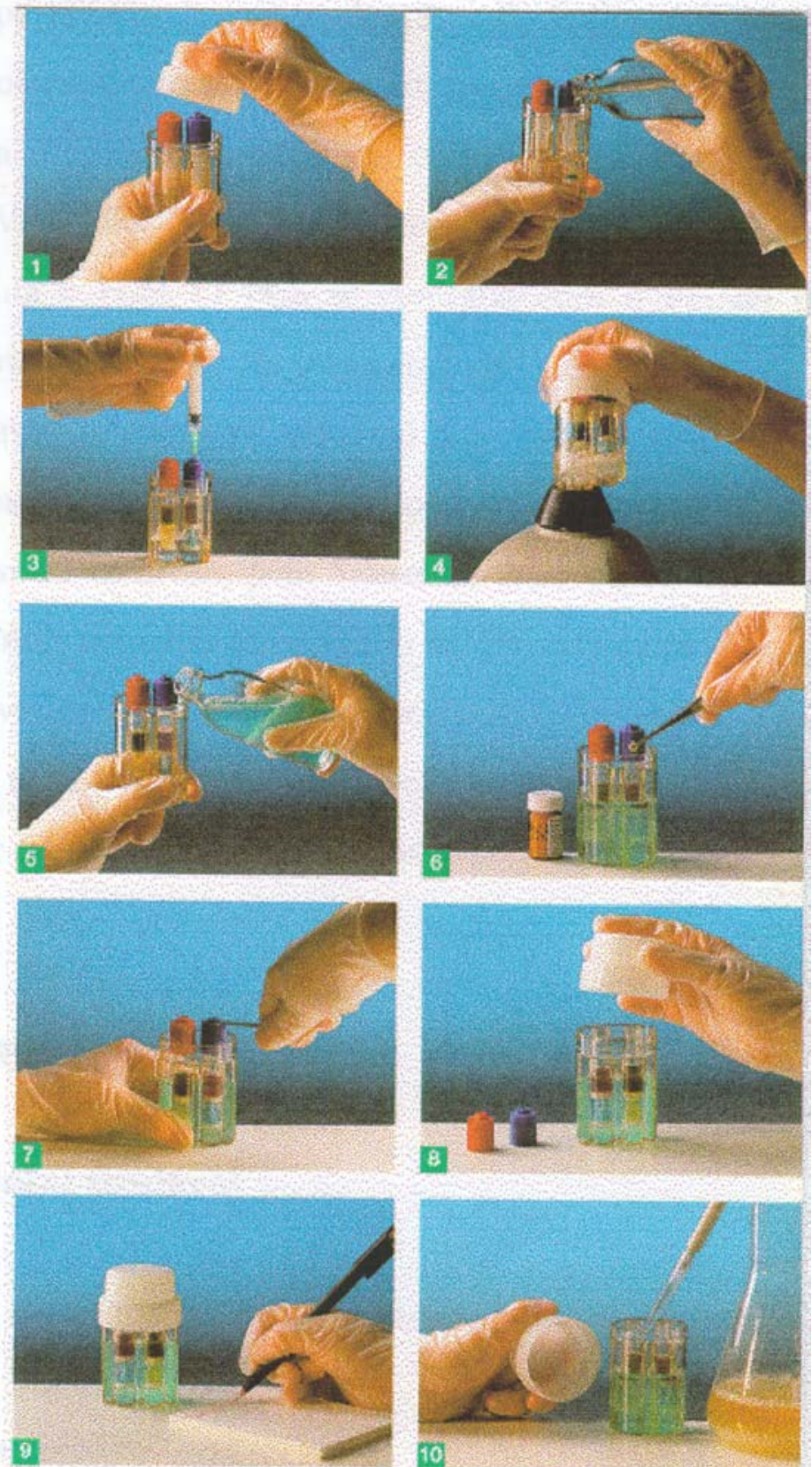

Figura 4 - Preparo e inoculação do kit "Oxoid Salmonella Rapid Test". Fonte: Unipath (1999)

A presença de Salmonella é indicada pela mudança de coloração do meio indicador superior ou dos dois meios, em cada um dos tubos. Qualquer grau de coloração preta no compartimento superior do tubo $\mathrm{A}$ e qualquer grau 
de coloração vermelha ou preta no compartimento superior do tubo $B$, indica um resultado positivo, como pode ser observado na Figura 5.

Tubo A:

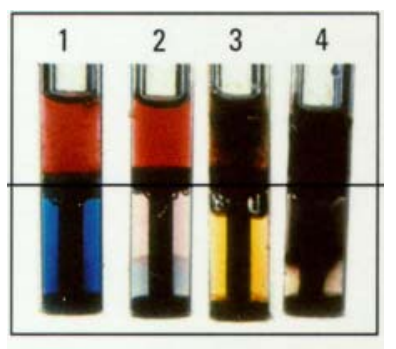

Coloração do meio indicador no compartimento superior:

1. Antes da incubação;

2. Resultado negativo - não há enegrecimento;

3. Resultado positivo - há algum enegrecimento;

4. Resultado positivo - há forte enegrecimento.

(a)

\section{Tubo B:}

Coloração do meio indicador no compartimento superior:

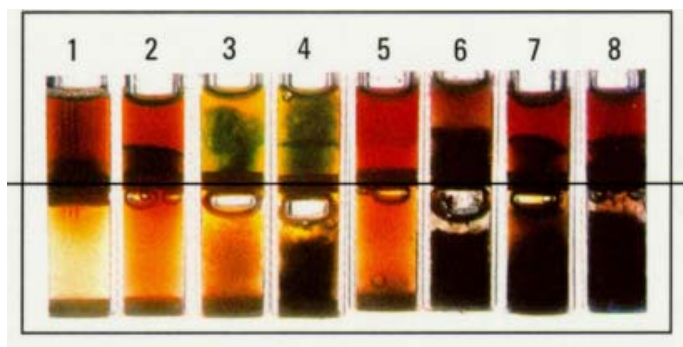

(b)

1. Antes da incubação;

2. Resultado negativo - há pequena mudança na coloração;

3. Resultado negativo - coloração esverdeada;

4. Resultado negativo - coloração amarelada;

5. Resultado positivo - somente coloração avermelhada;

6. Resultado positivo - suave avermelhamento e enegrecimento;

7. Resultado positivo - coloração vermelha;

8. Resultado positivo - coloração preta.

Figura 5 - Leitura e interpretação dos tubos A (a) e B (b) para análise de Salmonella.

Fonte: Unipath (1999) 


\subsubsection{Contagem de Staphylococcus aureus}

Para a contagem presuntiva de Staphylococcus aureus foi utilizado o método de contagem direta em placas. Das diluições $10^{-1}$ e $10^{-2}$ foram retiradas alíquotas de $0,1 \mathrm{~mL}$ para proceder o espalhamento em placas de Petri com o meio Ágar Baird-Parker (BPA), previamente preparadas e secas. O inóculo foi espalhado com uma alça de Drigalsky até que todo o excesso de líquido fosse absorvido. Após a secagem completa, as placas foram incubadas a $35-37^{\circ} \mathrm{C}$ por 24 horas (Figura 6 ). Para a contagem presuntiva foi utilizado um microscópio estereoscópico e contadas as colônias típicas de $S$. aureus: pretas, brilhantes, circulares, lisas, convexas, e com halo ao redor. Para confirmação foram selecionadas algumas colônias típicas para teste de Gram, catalase, coagulase e Staphy - Test.

Teste de Catalase: Adicionou-se algumas gotas de água oxigenada (peróxido de hidrogênio) $3 \%$ a cultura e observou-se a ocorrência ou não de borbulhamento imediato.

Teste de coagulase: Inoculou-se a cultura em caldo Brain Heart Infusion $(\mathrm{BHI})$ e incubou-a a $37^{\circ} \mathrm{C}$ por $18-24$ horas. Transferiu-se $0,2 \mathrm{ml}$ da cultura para um tubo e adicionou-se $0,5 \mathrm{ml}$ de Coagulase Plasma-EDTA. Misturou em rotações, sem agitar e incubou a $37^{\circ} \mathrm{C}$, observando a cada hora se houve formação de coágulo.

Staphy - Test: Depositou-se sobre uma lâmina uma gota de cada um dos reativos (Staphy Test $R$ - hemácias sensibilizadas com hemolisina e fibrinogênio; e Stapht Test $C$ - hemácias idênticas ao do primeiro reativo, porém não sensibilizadas com hemolisina e fibrinigênio). Adicionou-se a cada uma das gotas dos reativos 1 colônia suspeita com uma alça e agitou com movimentos circulares. Resultados: quando a reação de aglutinação foi fortemente positiva dentro de 5 segundos no reagente Staphy - Test R e negativa no Staphy - Test C, concluiu-se que a colônia era de Staphylococcus aureus. Quando a reação foi negativa nos dois reagentes, concluiu-se que não era Staphylococcus aureus. 
Os resultados obtidos foram comparados com os padrões vigentes no país para outros tipos de carnes, utilizadas para consumo humano, uma vez que não existem padrões específicos para carnes de animais silvestres.

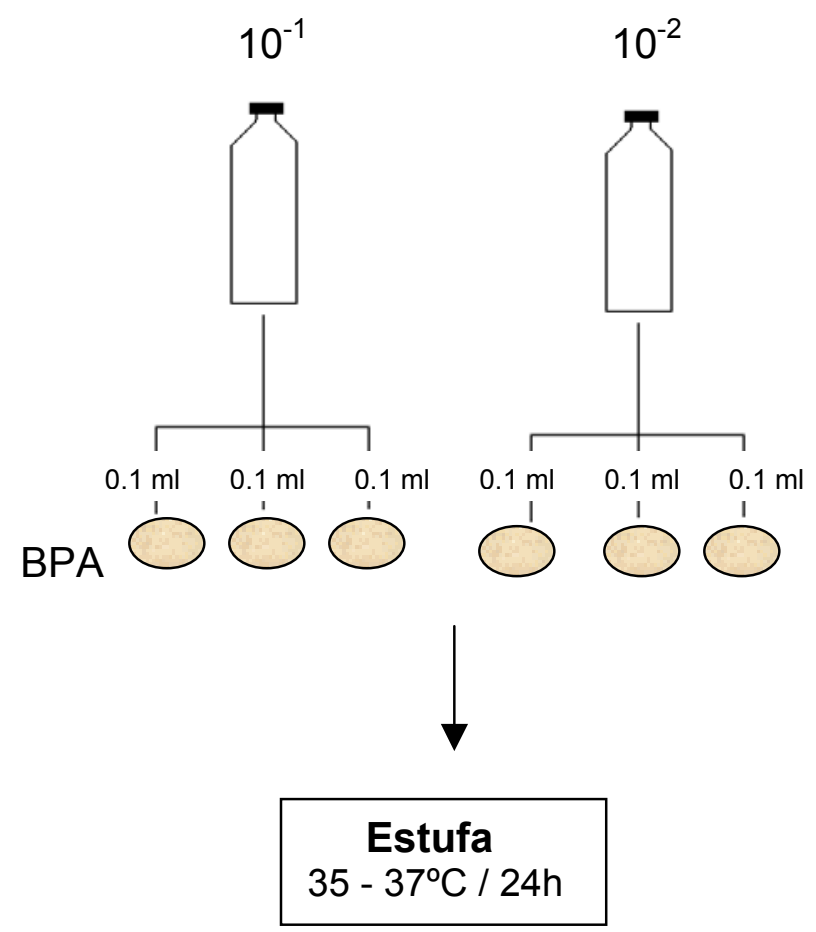

Figura 6 - Procedimento para a contagem de Staphylococcus aureus.

\subsubsection{Contagem de Clostridium Sulfito-Redutores a $46^{\circ} \mathrm{C}$}

Para a contagem de Clostridium sulfito-redutores foi utilizado o metódo de plaqueamento em profundidade. Após serem feitas as diluições foram retiradas alíquotas de $1 \mathrm{ml}$ da diluição $10^{-1}$ e inoculadas em placas de Petri previamente esterilizadas. Em cada placa inoculada foram adicionados $15 \mathrm{ml}$ do meio Sulfito-Polimixina-Sulfadiazina-Agar (SPS-A), previamente fundido e resfriado até a temperatura de $45^{\circ} \mathrm{C}$. $\mathrm{O}$ inóculo foi misturado ao meio de cultura através de movimentos circulares suaves e em movimentos na forma de oito. Após a solidificação do ágar adicionou-se uma sobrecapa do meio. As placas com o meio totalmente solidificado foram invertidas e incubadas em jarra de anaerobiose a $46^{\circ} \mathrm{C}$ por 48 horas (Figura 7). A contagem foi feita com o auxílio 
de uma lupa, em um contador de colônias tipo Quebec. Foram consideradas colônias de Clostridium sulfito-redutores todas as colônias pretas, típicas em SPS-A. Todas as análises foram feitas em triplicatas e obtida a média aritmética das contagens das UFC.

Os resultados obtidos foram comparados com os padrões vigentes no país para outros tipos de carnes, utilizadas para consumo humano, uma vez que não existem padrões específicos para carnes de animais silvestres.

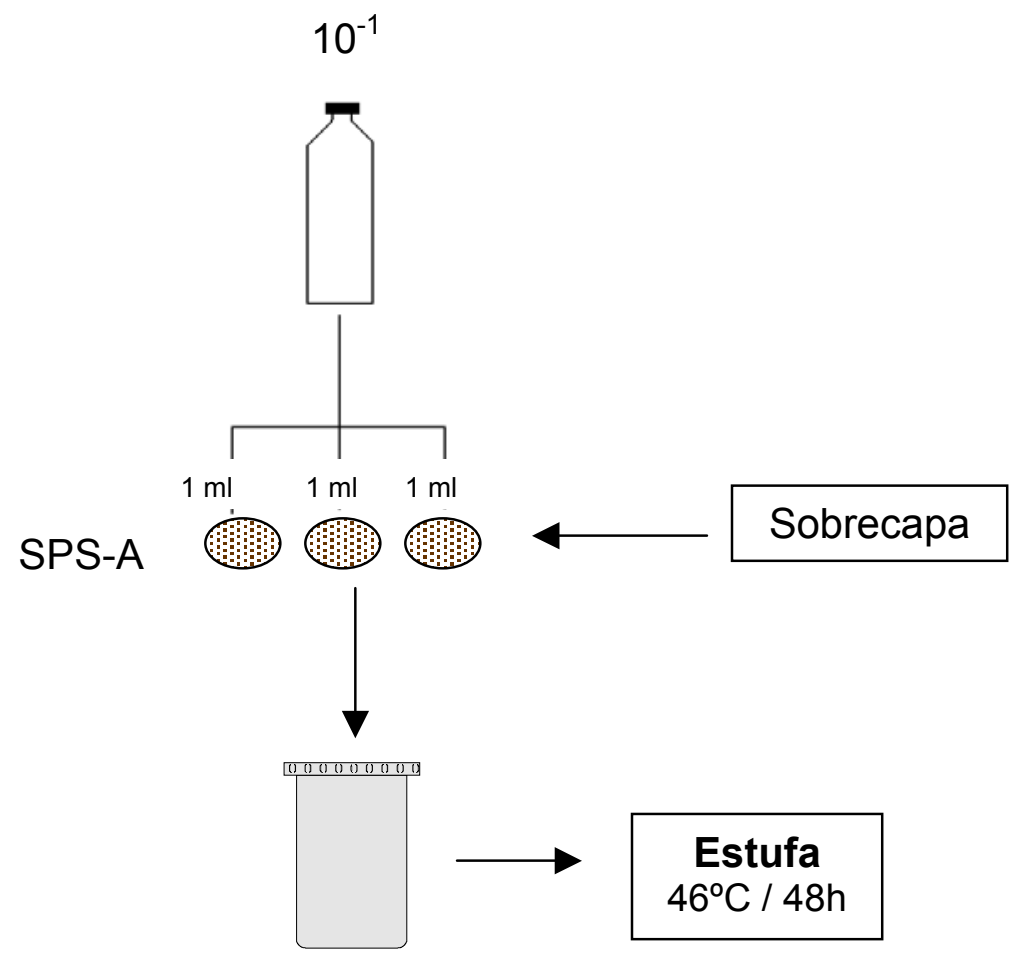

Jarra de anaerobiose

Figura 7 - Procedimento para contagem de Clostridium Sulfito-Redutores. 


\subsection{Análise estatística}

Dos resultados obtidos nas análises microbiológicas realizadas, foi feita a Análise Estatística Descritiva e calculado o Coeficiente de Variação entre as amostras, para os grupos de microrganismos avaliados, através do Statistical Analyses System (SAS, 1987). 


\section{RESULTADOS E DISCUSSÃO}

Os resultados das análises microbiológicas realizadas encontram-se nas Tabelas 2, 3, 4, 5, 6 e 7.

$\mathrm{Na}$ Tabela 8 estão representados os coeficientes de variação entre as amostras de cada carne, encontrados através da análise estatística descritiva.

No Quadro 10 encontram-se os resultados das análises de presença/ausência de Salmonella.

Nas Figuras 8, 9, 10, 11, 12 e 13 estão representados os resultados convertidos em $\log _{10}$.

A ilustração dos resultados das análises de Salmonella pode ser visualizada na Figura 14.

Tabela 2. Contagem total de microrganismos mesófilos aeróbios nas carnes de capivara, cateto e javali in natura. ${ }^{1}$

\begin{tabular}{cccc}
\hline Amostra & Capivara & Cateto & Javali \\
\hline 1 & $1,86 \times 10^{4}$ & $2,00 \times 10^{5}$ & $3,65 \times 10^{4}$ \\
2 & $2,67 \times 10^{3}$ & $2,64 \times 10^{5}$ & $7,50 \times 10^{3}$ \\
3 & $6,11 \times 10^{3}$ & $1,51 \times 10^{6}$ & $1,85 \times 10^{4}$ \\
4 & $1,20 \times 10^{5}$ & $1,70 \times 10^{4}$ & $2,00 \times 10^{4}$ \\
5 & $1,44 \times 10^{4}$ & $5,15 \times 10^{3}$ & $1,95 \times 10^{4}$ \\
6 & $1,07 \times 10^{3}$ & $1,07 \times 10^{4}$ & $3,32 \times 10^{4}$ \\
7 & $2,02 \times 10^{3}$ & $4,90 \times 10^{3}$ & $6,23 \times 10^{3}$ \\
8 & $2,40 \times 10^{4}$ & $4,16 \times 10^{3}$ & $1,15 \times 10^{4}$ \\
9 & $1,50 \times 10^{3}$ & $3,60 \times 10^{3}$ & $1,63 \times 10^{4}$ \\
\hline
\end{tabular}

${ }^{1}$ Médias de 3 repetições, expressas em UFC / g de carne. 
Os mesmos resultados da Tabela 2 convertidos em $\log _{10}$ podem agora ser vistos na forma de gráfico.

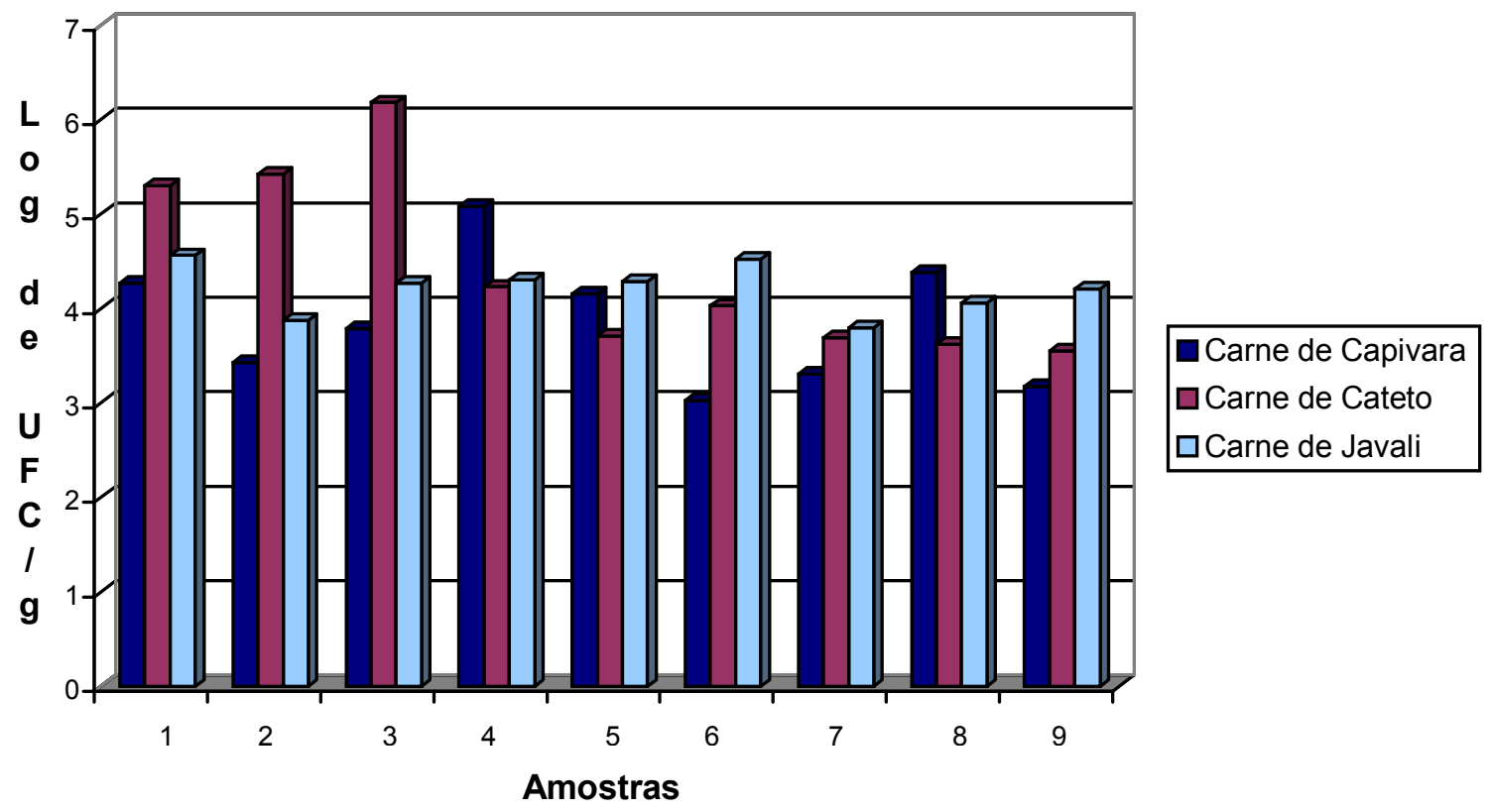

Figura 8 - Contagem total de microrganismos mesófilos aeróbios nas carnes de capivara, cateto e javali in natura.

Como pode ser observado na Tabela 2, apesar da grande diferença entre as amostras, todas enquadram-se nos padrões já vigentes no país, que eram, segundo a Comissão Nacional de Normas e Padrões para Alimentos de 1978 , de $3,0 \times 10^{6} \mathrm{UFC} / \mathrm{g}$. A maior contagem obtida foi a da amostra 3 da carne de cateto $\left(1,51 \times 10^{6} \mathrm{UFC} / \mathrm{g}\right)$, que apresentou-se muito próxima desse limite estabelecido.

Apesar da legislação brasileira atual não estabelecer um padrão para contagem total de mesófilos para carnes cruas, sabe-se que um alimento dessa natureza que contenha uma elevada contagem microbiana $\left(10^{5}\right.$ - $10^{6} \mathrm{UFC} / \mathrm{g}$ ou $\mathrm{ml}$ ) apresenta risco de estar deteriorado ou se deteriorando, além de ter suas características nutricionais e organolépticas comprometidas. 
Tabela 3. Contagem total de microrganismos psicrotróficos nas carnes de capivara, cateto e javali in natura. ${ }^{1}$

\begin{tabular}{cccc}
\hline Amostra & Capivara & Cateto & Javali \\
\hline 1 & $9,20 \times 10^{3}$ & $8,06 \times 10^{5}$ & $5,63 \times 10^{3}$ \\
2 & $1,68 \times 10^{4}$ & $7,13 \times 10^{5}$ & $1,46 \times 10^{6}$ \\
3 & $2,88 \times 10^{3}$ & $4,30 \times 10^{6}$ & $1,47 \times 10^{6}$ \\
4 & $1,60 \times 10^{4}$ & $2,00 \times 10^{3}$ & $8,33 \times 10^{2}$ \\
5 & $3,00 \times 10^{2}$ & $2,66 \times 10^{2}$ & $3,33 \times 10^{2}$ \\
6 & $1,00 \times 10^{1}$ & $3,25 \times 10^{3}$ & $1,00 \times 10^{2}$ \\
7 & $3,16 \times 10^{2}$ & $6,33 \times 10^{2}$ & $9,40 \times 10^{4}$ \\
8 & $2,23 \times 10^{3}$ & $5,00 \times 10^{2}$ & $1,06 \times 10^{5}$ \\
9 & $1,00 \times 10^{2}$ & $7,65 \times 10^{2}$ & $6,63 \times 10^{5}$ \\
\hline
\end{tabular}

${ }^{1}$ Médias de 3 repetições, expressas em UFC / g de carne.

Embora a legislação nacional atual também não mencione limites para a contaminação por microrganismos psicrotróficos em carnes cruas, ao se observar as contagens da amostra 3 da carne de cateto, e das amostras 2 e 3 da carne de javali, verificam-se valores superiores e/ou muito próximos àqueles mencionados pela Comissão Nacional de Normas e Padrões para Alimentos de 1978 para microrganismos mesófilos, que eram níveis máximos de 3,0 × 106 UFC/g de carne crua. Nota-se, portanto, uma elevada contaminação por microrganismos psicrotróficos em algumas amostras, principalmente pelo fato de que quando há menção de níveis tolerados de psicrotróficos para um alimento, os mesmos são bastante inferiores aos níveis tolerados para microrganismos mesófilos .

As amostras de carnes de cateto e de javali, analisadas, mostraram níveis mais elevados de contaminação por microrganismos psicrotróficos, quando comparadas às amostras de carne de capivara. 


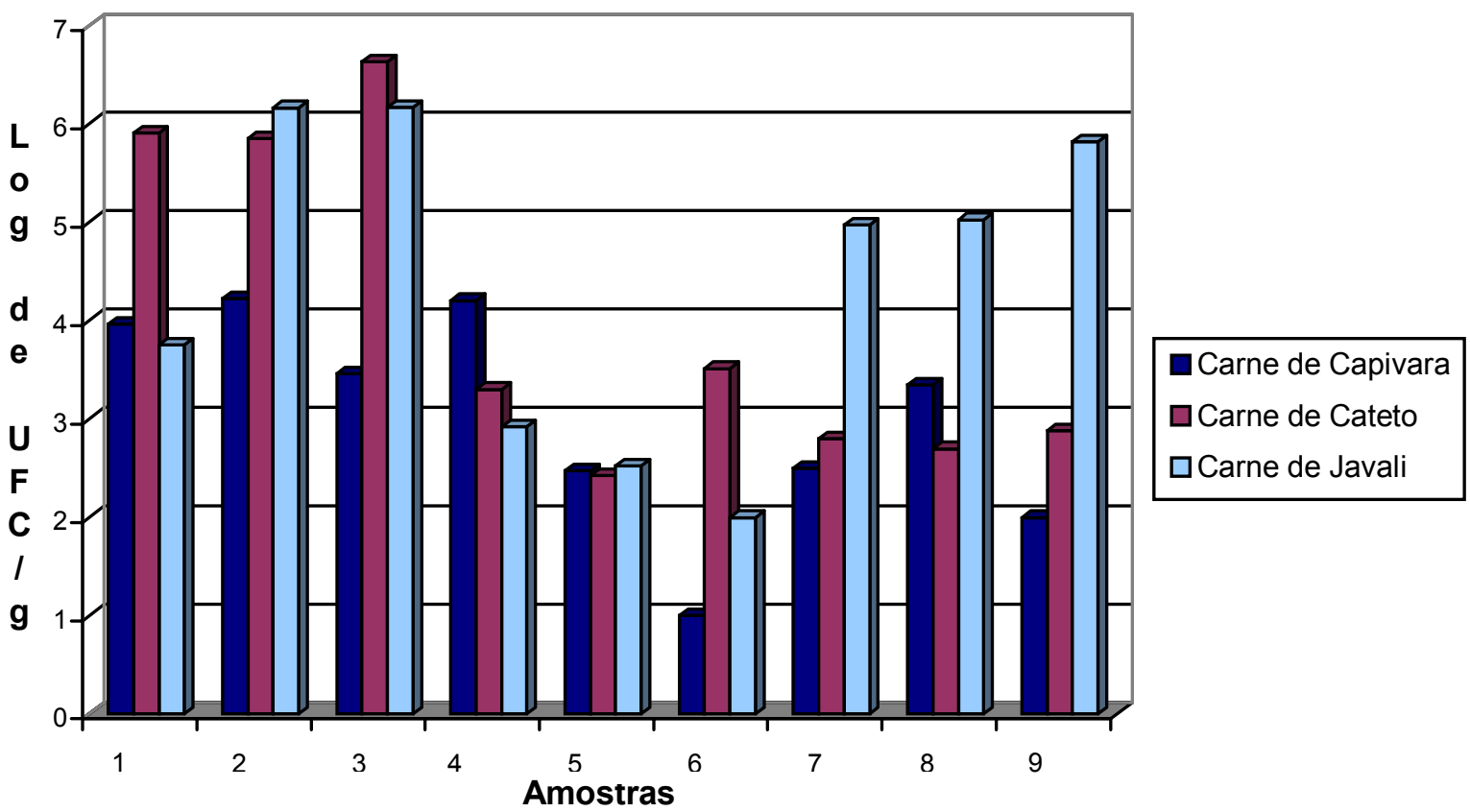

Figura 9 - Contagem total de microrganismos psicrotróficos nas carnes de capivara, cateto e javali in natura.

Tabela 4. Contagem de $S$. aureus nas carnes de capivara, cateto e javali in natura. ${ }^{1}$

\begin{tabular}{cccc}
\hline Amostra & Capivara & Cateto & Javali \\
\hline 1 & $2,60 \times 10^{2}$ & $4,30 \times 10^{3}$ & $2,30 \times 10^{2}$ \\
2 & $9,00 \times 10^{2}$ & $4,65 \times 10^{2}$ & $8,00 \times 10^{2}$ \\
3 & $1,50 \times 10^{3}$ & $1,30 \times 10^{2}$ & $4,73 \times 10^{3}$ \\
4 & $3,33 \times 10^{2}$ & $2,03 \times 10^{3}$ & $6,33 \times 10^{2}$ \\
5 & $3,33 \times 10^{2}$ & $5,33 \times 10^{2}$ & $3,00 \times 10^{2}$ \\
6 & $2,00 \times 10^{2}$ & $<10^{2}$ & $<10^{2}$ \\
7 & $2,16 \times 10^{2}$ & $1,00 \times 10^{2}$ & $4,50 \times 10^{2}$ \\
8 & $<10^{2}$ & $6,67 \times 10^{1}$ & $2,33 \times 10^{2}$ \\
9 & $4,30 \times 10^{2}$ & $4,30 \times 10^{2}$ & $3,45 \times 10^{2}$ \\
\hline
\end{tabular}

${ }^{1}$ Médias de 3 repetições, expressas em UFC / g de carne. 


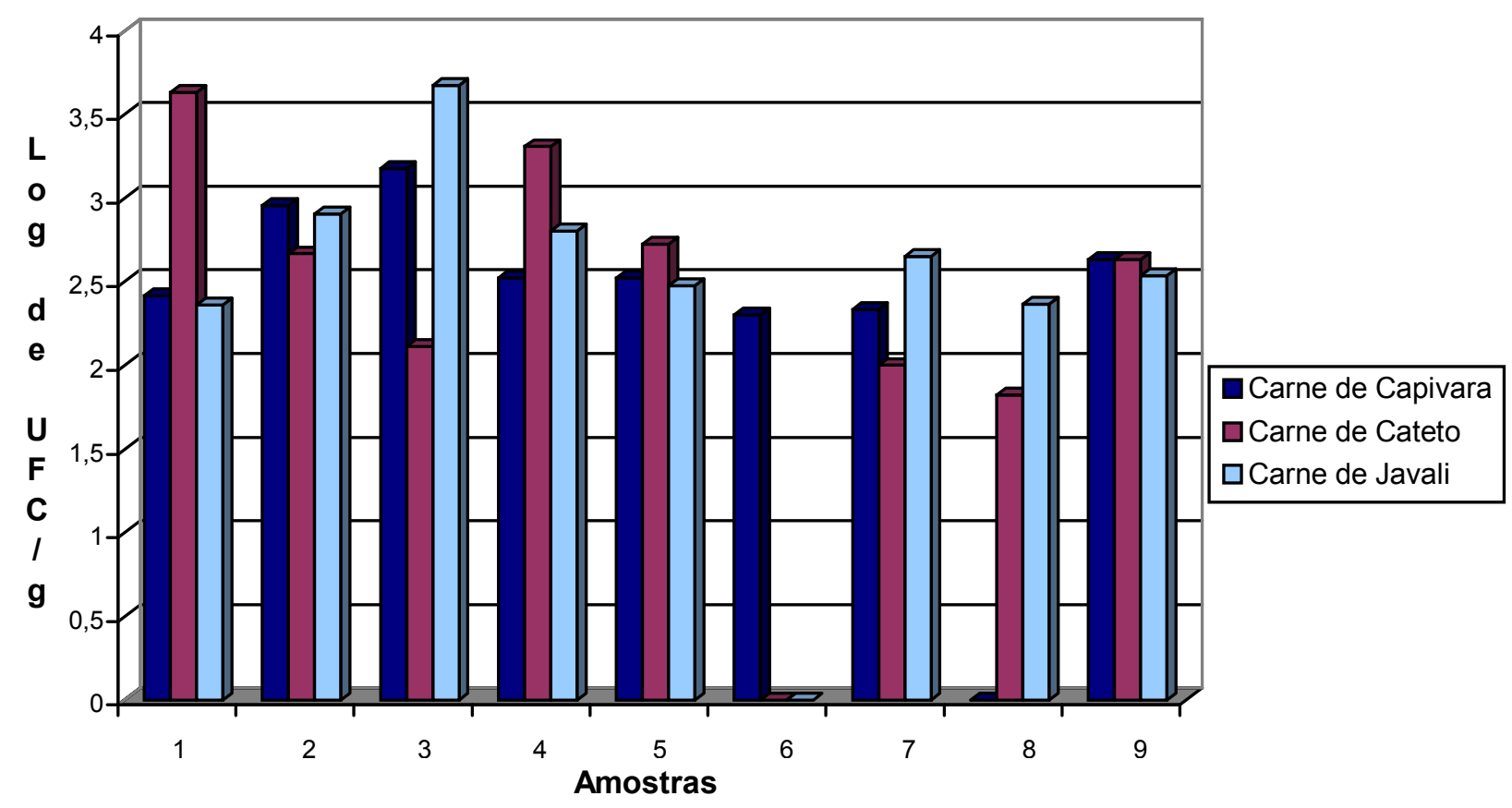

Figura 10 - Contagem de $S$. aureus nas carnes de capivara, cateto e javali in natura.

$\mathrm{Na}$ Tabela 4, pode-se observar as contagens de S. aureus. Embora todas as amostras analisadas tenham apresentado contagens dentro dos limites tolerados $\left(1,0 \times 10^{3}-5,0 \times 10^{3} \mathrm{UFC} / \mathrm{g}\right)$ de $S$. aureus pela resolução RDC n¹2 da Agência Nacional de Vigilância Sanitária (ANVISA) de 02.02.2001, as amostras de número 3 das carnes de capivara e javali e as de número 1 e 4 da carne de cateto, apresentaram maior contaminação por esta bactéria. Vale lembrar que os referidos valores citados, dizem respeito a produtos cárneos crus, resfriados ou congelados, uma vez que a resolução não cita padrões de $S$. aureus para carne in natura. Mesmo dentro dos padrões citados, estas amostras referidas se constituem em risco maior de uma possível intoxicação alimentar, caso as condições de armazenamento/comercialização destas carnes não sigam as recomendações, principalmente quanto a temperatura de armazenamento, que não deve ser superior a $4^{\circ} \mathrm{C}$. 
Já em relação aos padrões mencionados pela Comissão Nacional de Normas e Padrões para Alimentos de 1978, que estipula como máximo de $S$. aureus para carnes cruas $1,0 \times 10^{3} \mathrm{UFC} / \mathrm{g}$, as amostras de número 3 das carnes de capivara e javali e as de número 1 e 4 da carne de cateto, apresentaram contagens superiores às mencionadas, sendo consideradas insatisfatórias para o consumo humano, sob o aspecto higiênico-sanitário. Já na carne de jacaré, analisada por Hoffman \& Romanelli (1998), todas as amostras apresentaram condições insatisfatórias devido a presença de $S$. aureus, segundo a legislação paulista sobre pescado. Não foram encontrados dados na literatura referentes às condições microbiológicas das carnes de capivara, cateto e javali.

Tabela 5. Contagem de Clostridium sulfito-redutores nas carnes de capivara, cateto e javali in natura. ${ }^{1}$

\begin{tabular}{cccc}
\hline Amostra & Capivara & Cateto & Javali \\
\hline 1 & $<10$ & $<10$ & 26 \\
2 & 20 & 17,0 & 7,0 \\
3 & $<10$ & 7,0 & 7,0 \\
4 & 3,0 & $<10$ & 10 \\
5 & 10 & $<10$ & 10 \\
6 & 3,0 & 3,0 & 3,0 \\
7 & 3,0 & 7,0 & 10 \\
8 & 3,0 & 13,0 & 7,0 \\
9 & 16 & 3,0 & 3,0 \\
\hline
\end{tabular}

${ }^{1}$ Médias de 3 repetições, expressas em UFC / g de carne.

De acordo com a Tabela 5, que representa os resultados das contagens de Clostridium sulfito-redutores, todas as amostras apresentaram-se dentro dos limites estabelecidos pela ANVISA, através da resolução RDC $n^{0} 12$ de 
02.02.2001, para produtos cárneos crus, resfriados ou congelados, que é de 5,0 $\times 10^{2}-3,0 \times 10^{3} \mathrm{UFC} / g$ de produto, uma vez que a resolução não cita tais padrões para carne in natura,

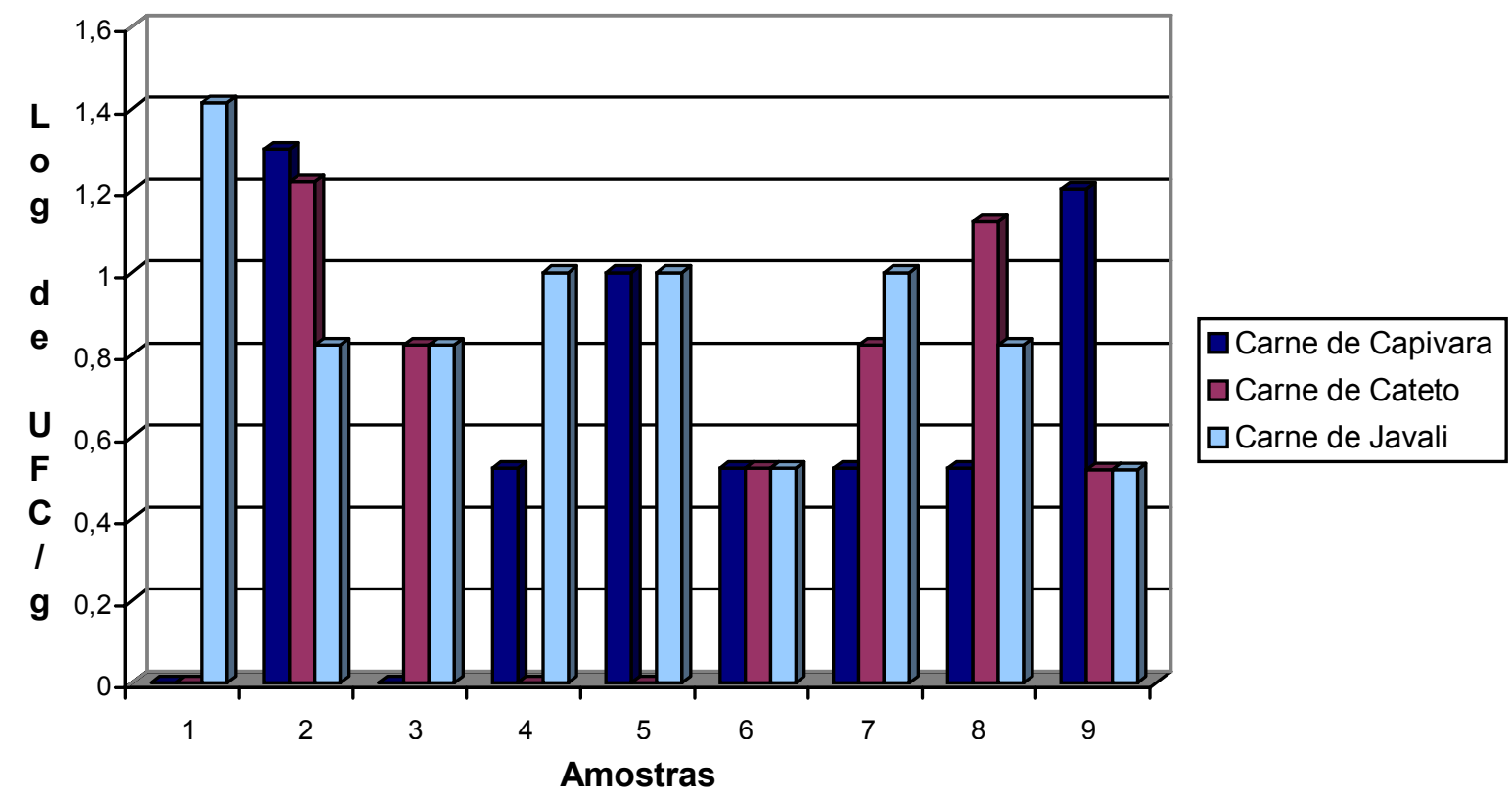

Figura 11 - Contagem de Clostridium sulfito-redutores nas carnes de capivara, cateto e javali in natura. 
Tabela 6. Número Mais Provável (NMP) de coliformes totais nas carnes de capivara, cateto e javali in natura. ${ }^{1}$

\begin{tabular}{cccc}
\hline Amostra & Capivara & Cateto & Javali \\
\hline 1 & 5 & 2.400 & 2,3 \\
2 & 0,9 & 2.400 & 4,3 \\
3 & 3,5 & 2,5 & 0,9 \\
4 & 46 & 0,4 & 24 \\
5 & 24 & 2,3 & 240 \\
6 & 1 & 0,4 & 10,6 \\
7 & 2,3 & 2,5 & 9,3 \\
8 & 240 & 240 & 240 \\
9 & 0,5 & 1,3 & 0,4 \\
\hline
\end{tabular}

${ }^{1}$ Médias de 3 repetições, expressas em NMP / g de carne.

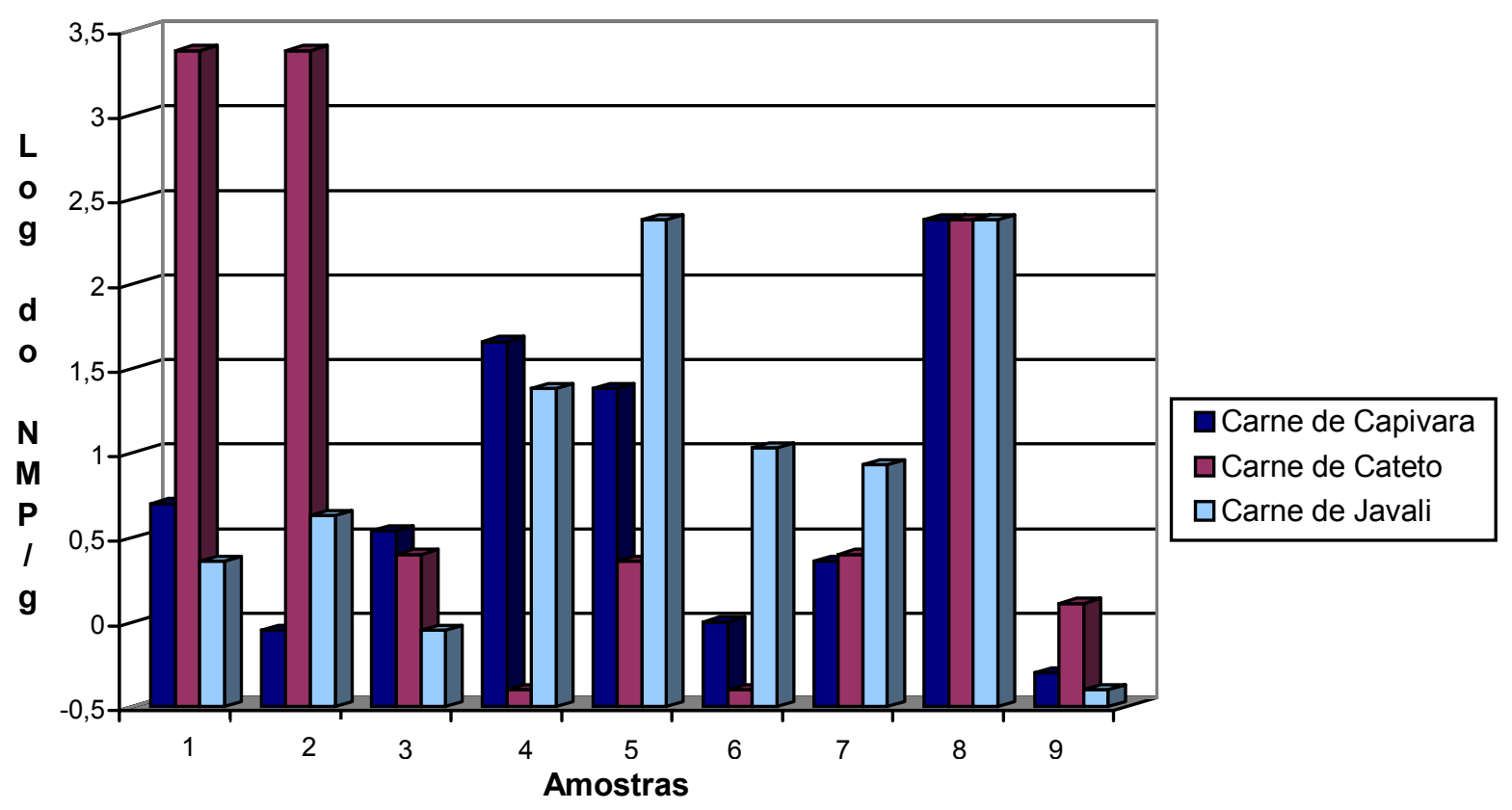

Figura 12 - NMP de coliformes totais nas carnes de capivara, cateto e javali in natura. 
Tabela 7. NMP de coliformes fecais nas carnes de capivara, cateto e javali in natura. ${ }^{1}$

\begin{tabular}{cccc}
\hline Amostra & Capivara & Cateto & Javali \\
\hline 1 & 0,4 & 59 & 0,4 \\
2 & $<0,3$ & 4 & 0,9 \\
3 & $<0,3$ & 2,5 & $<0,3$ \\
4 & 5,9 & $<0,3$ & $<0,3$ \\
5 & 1,3 & 0,4 & 0,4 \\
6 & 0,4 & $<0,3$ & 0,4 \\
7 & $<0,3$ & $<0,3$ & 0,4 \\
8 & $<0,3$ & 0,5 & $<0,3$ \\
9 & $<0,3$ & $<0,3$ & $<0,3$ \\
\hline
\end{tabular}

${ }^{1}$ Médias de 3 repetições, expressas em NMP / $\mathrm{g}$ de carne.

$\mathrm{Na}$ Tabela 7 , a menção de valores $<0,3$ diz respeito a ausência de tubos positivos, ou seja, nenhum dos tubos inoculados mostrou fermentação da lactose com formação de gás.

Todas as amostras analisadas apresentaram-se dentro dos limites máximos estabelecidos pela ANVISA, através da resolução RDC $\mathrm{n}^{0} 12$ de 02.02.2001, para produtos cárneos crus, resfriados ou congelados, uma vez que a resolução não cita tais padrões para carne in natura, e pela Comissão Nacional de Normas e Padrões para Alimentos, de 1978, para carne crua, que

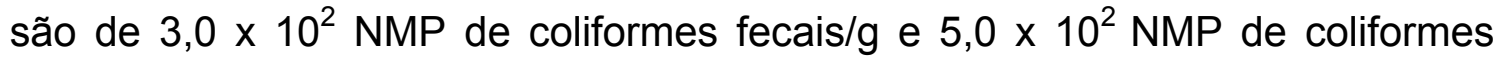
fecais/g, respectivamente. Piérard et al. (1997) analisando carne de javali encontraram em $27 \%$ das amostras, presença de verocitotoxina, produzida por E. coli, não sendo apresentada no entanto, a contagem de coliformes fecais.

$\mathrm{Na}$ Figura 13 os resultados convertidos em $\log _{10}$ podem ser visualizados. Mesmo encontrando-se dentro dos padrões legais vigentes, é 
possível observar que a amostra 1 da carne de cateto apresentou contagem bem superior as demais amostras analisadas.

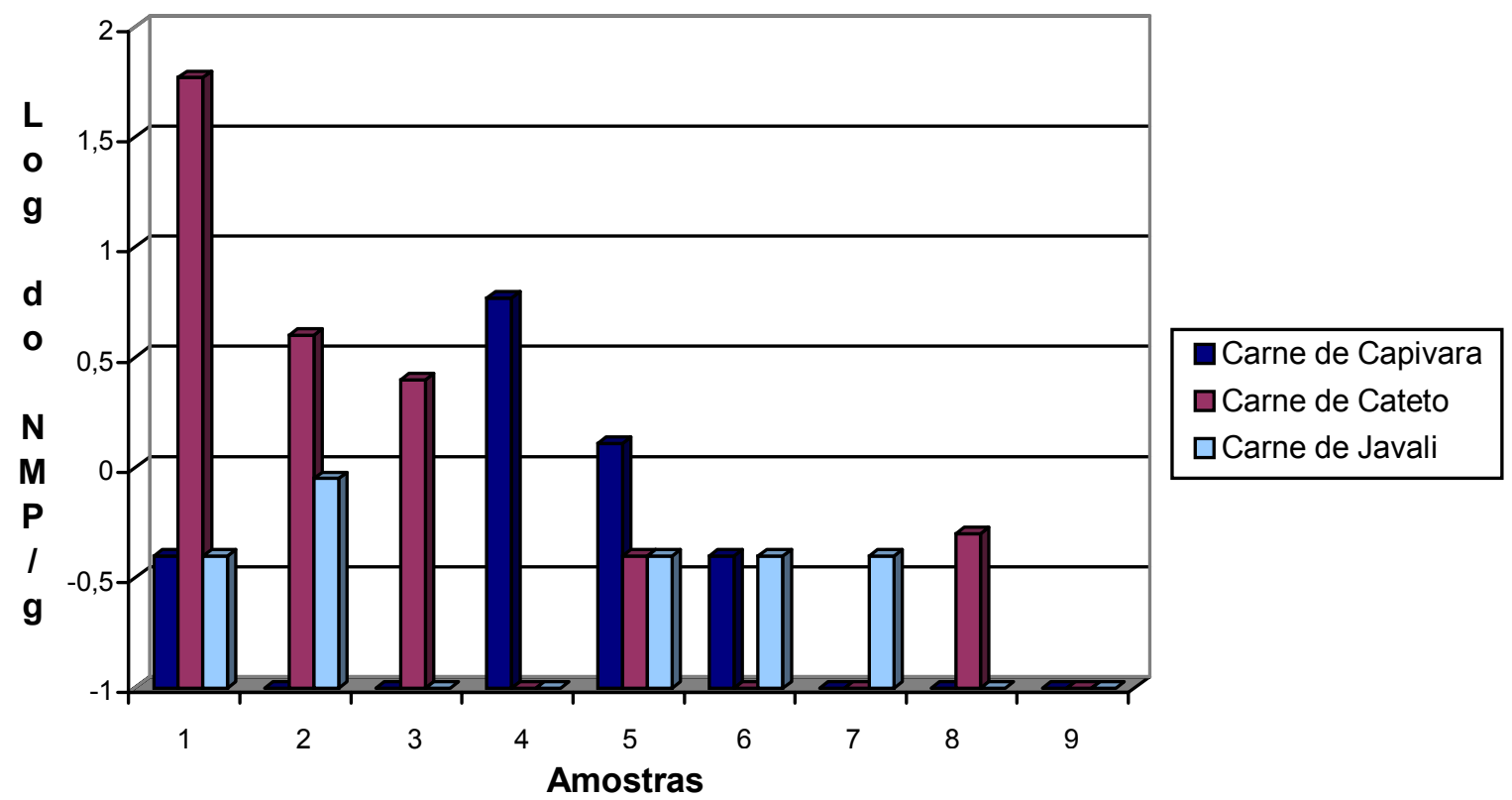

Figura 13 - Contagem de coliformes fecais nas carnes de capivara, cateto e javali in natura.

\begin{tabular}{|cccc|}
\hline Amostra & Capivara & Cateto & Javali \\
\hline $\mathbf{1}$ & Ausência & Presença & Ausência \\
2 & Ausência & Ausência & Ausência \\
3 & Ausência & Presença & Ausência \\
$\mathbf{4}$ & Ausência & Ausência & Ausência \\
$\mathbf{5}$ & Ausência & Ausência & Ausência \\
6 & Ausência & Ausência & Ausência \\
7 & Ausência & Ausência & Ausência \\
8 & Ausência & Ausência & Ausência \\
9 & Ausência & Ausência & Ausência \\
\hline
\end{tabular}

Quadro 10 - Presença/Ausência de Salmonella nas carnes de capivara, cateto e javali in natura. 
Pelos resultados do Quadro 10, nota-se que 2 das 9 (22\%) amostras de carne de cateto analisadas (amostras 1 e 3) apresentaram Salmonella em $25 \mathrm{~g}$ de amostra, o que as tornam impróprias para o consumo humano, de acordo com a resolução RDC n¹2 da ANVISA. Em nenhuma das amostras de carne de capivara e javali, analisadas no presente trabalho, houve detecção de Salmonella.

A presença de Salmonella em carne de animais silvestres é relatada por diversos autores. Leak et al. (1987) e Hoffman \& Romanelli (1998) verificaram a presença de Salmonella em carne de jacaré. Scott \& Foster (1997) encontraram $20 \%$ das amostras de carne de jacaré provenientes de cativeiro contaminadas com Salmonella. Adesiyun et al. (1998) encontraram 7\% das amostras de carne contaminadas por Salmonella entre animais silvestres ruminantes e não ruminantes. Os mesmos autores mostraram ainda que das amostras de carne de cateto proveniente de cativeiro, $40 \%$ encontravam-se contaminadas por este patógeno. Já em carne de javali, 2,2\% das amostras analisadas por Kanai et al. (1997) apresentaram Salmonella. 


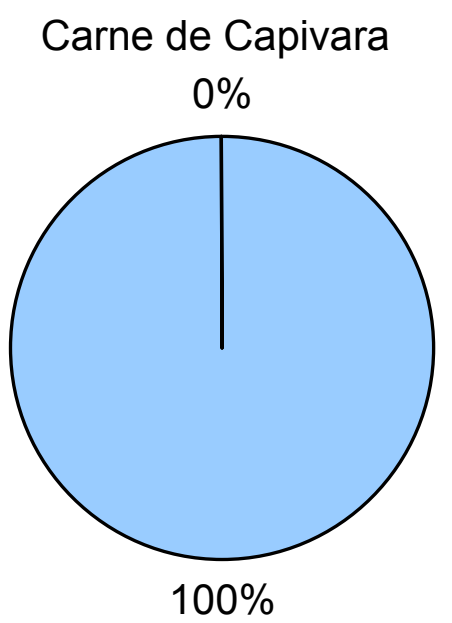

Ausência de Salmonella
Carne de Cateto

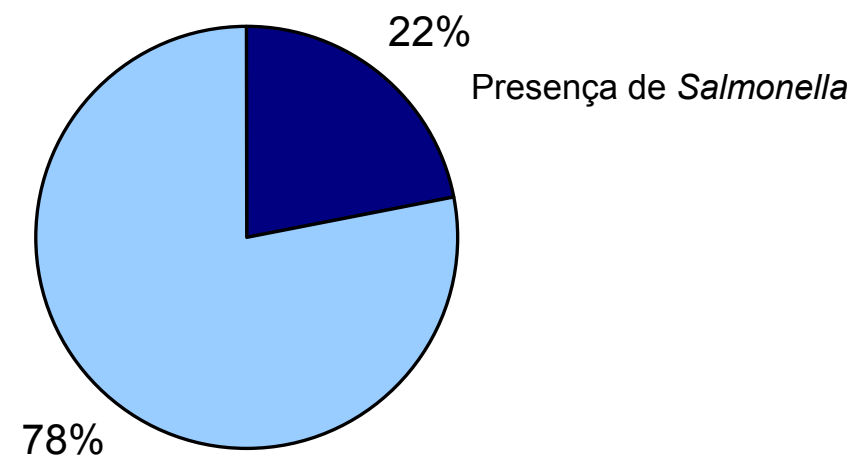

Ausência de Salmonella

Carne de Javali

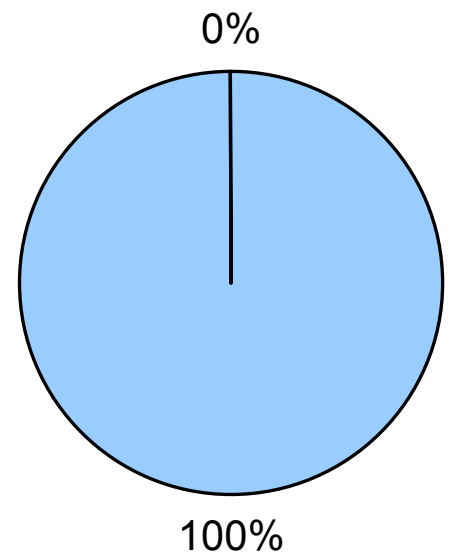

Ausência de Salmonella

Figura 14 - Presença/Ausência de Salmonella nas carnes de capivara, cateto e javali in natura. 
Tabela 8. Coeficientes de variação (\%).

\begin{tabular}{lccc}
\hline & Capivara & Cateto & Javali \\
\hline Mesófilos totais & 197,67 & 219,48 & 55,39 \\
Psicrotróficos totais & 130,025 & 217,59 & 148,57 \\
Staphylococcus aureus & 99,06 & 158,6 & 171,45 \\
Clostridium Sulfito-redutores & 108,55 & 108,94 & 74,33 \\
Coliformes totais & 217,38 & 186,35 & 174,0 \\
Coliformes fecais & 216,52 & 263,07 & 110,63 \\
\hline
\end{tabular}

A análise estatística descritiva apresentou um elevado coeficiente de variação entre as 9 amostras analisadas para cada tipo de carne. Apenas a contagem de mesófilos totais e Clostridium sulfito-redutores na carne de javali, apresentaram menores resultados. Esse alto grau de variação entre as amostras mostra que as condições microbiológicas das amostras não apresentaram uniformidade no decorrer das análises.

A variação na contaminação por microrganismos pode ser justificada por diversos fatores como sanidade do animal, tipo e condições de abate, transporte e armazenamento da carne.

A sanidade do animal altera a qualidade final da carne, microbiológica e organolepticamente. Sabe-se que a alimentação e a qualidade dos alimentos e da água ingerida podem debilitar a saúde animal ou até causar doenças. O "stress" também pode deixar o animal suscetível à doenças. A proximidade com o homem e o tipo de manejo adotado pelos produtores, como o cativeiro, leva o animal ao "stress", podendo diminuir a qualidade final da carne.

O abate deve ser levado em consideração uma vez que para animais silvestres não há uma legislação que regulamente o abate. Capivaras, catetos e javalis são abatidos em abatedouros de suínos, e não existem estudos comprovando que o modo como são abatidos seja adequado. $O$ estudo 
realizado por Hoffman \& Romanelli (1998) com jacarés, mostra que a carne dos animais mesmo sofrendo uma desinfecção com solução de hipoclorito de cálcio a 100 ppm durante 1 minuto após o abate, ainda apresentou níveis de Staphylococcus aureus acima do padrão e presença de Salmonella. As ferramentas utilizadas no abate também podem contribuir para a contaminação, assim como uma evisceração mal feita. A contaminação durante o abate também pode se dar devido a falta de higiene dos funcionários e do local de trabalho. Insetos e roedores atraídos pelos restos de carne, sangue e pêlos contribuem para o aumento da contaminação microbiana.

Após o abate, a carne deve ser resfriada para armazenamento ou transporte. Durante o transporte as oscilações da temperatura interna do veículo isotérmico possibilitam o desenvolvimento microbiano. É importante que o caminhão frigorífico esteja em bom estado de funcionamento, mantendo assim as condições originais da carne.

O armazenamento pode ser feito através da refrigeração ou do congelamento. Quando a carne é armazenada em ambiente refrigerado, ou seja, em temperaturas inferiores a $10^{\circ} \mathrm{C}$, a velocidade do crescimento microbiano é reduzida, aumentando assim a vida útil do alimento. Desse modo quanto menor a temperatura, maior será o tempo de conservação. É importante lembrar que o frio não elimina muitos dos microrganismos. Quando retornam à temperatura ambiente, começam a se multiplicar novamente, sendo esta a razão pela qual é importante manter baixas as temperaturas. Grandes oscilações da temperatura podem causar uma diminuição significativa na vida útil das carnes, sendo necessária uma revisão periódica das câmaras frias ou refrigeradores, bem como dos geradores de energia (Pardi et al., 1993). 


\section{CONCLUSÕES}

- Apesar da legislação brasileira atual não estabelecer padrões para contagem total de bactérias mesófilas e psicrotróficas em carnes cruas, algumas amostras analisadas apresentaram contagens elevadas desses microrganismos $\left(10^{5}-10^{6} \mathrm{UFC} / \mathrm{g}\right)$, o que pode acelerar a deterioração do produto, além de outros inconvenientes.

- 1 das 9 (11\%) amostras da carne de capivara analisadas apresentou contagem elevada de $S$. aureus.

- 2 das $9(22 \%)$ amostras da carne de cateto analisadas mostraram-se impróprias para o consumo humano, de acordo com a Resolução - RDC $\mathrm{n}^{\circ} 12$ da ANVISA, por apresentarem Salmonella em $25 \mathrm{~g}$ de amostra e 1 das $9(11 \%)$ amostras apresentou contagem elevada de S.aureus.

- 1 das $9(11 \%)$ amostras da carne de javali analisadas apresentou contagem elevada de S.aureus.

- A análise estatística descritiva apresentou um elevado coeficiente de variação devido a grande heterogeneidade das amostras.

- As amostras de carne de cateto analisadas apresentaram maior contaminação microbiológica do que as demais. 


\section{REFERÊNCIAS BIBLIOGRÁFICAS}

ADESIYUN, A.A.; SEEPERSADSINGH, N.; INDER, L.; CAESAR, K. Some bacterial enteropathogens in wildlife and racing pigeons from Trinidad. Journal of Wildlife Diseases, v.34, n.1, p.73-80, 1998.

AGÊNCIA NACIONAL DE VIGILÂNCIA SANITÁRIA (ANVISA). Resolução RDC n¹2 de 02 de janeiro de 2001. Disponível em: <http:www.anvisa.gov.br>Acesso em: 05 mar. 2002.

ARIAS, J.F.; GARCÍA, F.; RIVERA, M.; LÓPEZ, R. Trypanosoma evansi in capybara from Venezuela. Journal of Wildlife Diseases, v.33, n.2, p.359-361, 1997.

ASSOCIAÇÃO BRASILEIRA DE NORMAS TÉCNICAS. Bactérias coliformes totais, coliformes fecais e Escherichia coli em alimentos: determinação do número mais provável (NMP): mb-3463. Rio de Janeiro, 1991. 7p.

BANDARRA, E.P.; SILVA, C.A; LANGONI, H.; UIEDA, W. Septicemia por Salmonella sp. em capivara (Hydrochaeris hidrochaeris). Semina, v.16, n.1, p.153-155, 1995. 
BELLANTONI, E.S.; KRAUSMAN, P.R. Habitat use by collared peccaries in an urban environment. Southwestern Naturalist, v.38, n.4, p.345-351, 1993.

BENNETT, R.W.; LANCETTE, G.A. Staphylococcus aureus. In: FDA bacteriological analytical manual. 8.ed. Washington: AOAC International, 1995. p.12.01-12.05.

BOERS, R.H.; DIJKMANN, K.E.; WIJNGAARDS, G. Shelf-life of vaccumpackaged wild boar meat in relation to that vaccum-packaged pork: relevance of intrinsic fators. Meat Science, v.37, n.1, p.91-102, 1994.

BOURGEOIS, C.M.; MESCLE, J.F.; ZUCCA, J. Microbiología alimentaria. aspectos microbiológicos de la seguridad y calidad alimentaria. Zaragoza: Editorial Acribia, 1994. 437p.

BRASIL. Comissão Nacional de Normas e Padrões para Alimentos. Resolução $n^{\circ}$ 13/78. Diário Oficial, 25 de julho de 1978. p.11.61611.617.

BYERS, J.A.; BEKOFF, M. Social spacing and cooperative behavior of the collared peccary Tayassu tajacu. Journal of Mammalogy, v.62, n.4, p.764-785, 1981.

CHIPLEY, J.R.; CREMER, M.L. Microbiological problems in the food service industry. Food Technology, v.34, n.10, p.59-68, 1980.

CLIVER, D.O. Foodborne diseases. Califórnia: Academic Press, 1990. $395 p$. 
CORN, J.L.; WARREN, R.J. Seasonal food habits of the collared peccaries in South Texas. Journal of Mammalogy, v.66, n.1, p.155-159, 1989.

DIFCO LABORATORIES. Dehidrated culture media and reagentes for microbiology. 10.ed. Detroit, 1984. 1155p.

DOYLE, M.P.; SCHUENI, J.L. Survival and characteristics of E. coli associated with hemorrhagic colitis. Applied and Environmental Microbiology, v.48, n.4, p.855-856, 1984.

ELEY, A.R. Intoxicaciones alimentarias de etiología microbiana. Zaragoza: Ediorial Acribia, 1994. 208p.

ELEY, A.R. Microbial food poisoning. 2.ed. London: Chapman \& Hall, 1996. 211p.

FÉRON, E.M. New food sources conservation of biodiversity and sustainable development: can unconventional animal species contribute to feeding the world? Biodiversity and Conservation, v.4, n.3, p.233240, 1995.

FRANCO, B.D.G.M.; LANDGRAF, M. Microbiologia dos alimentos. São Paulo: Atheneu, 1996. 182p.

FRASSON, C.; SALGADO, J.M. Animais silvestres: capivara - uma opção contra a fome e a deficiência em proteína animal. In: SIMPÓSIO INTERFACE NUTRIÇÃO X AGRICULTURA, 2., Piracicaba, 1990. Anais. Piracicaba: FEALQ, 1990. p.175-200. 
FRAZIER, W.C.; WESTHOFF, D.C. Microbiologia de los alimentos. Zaragoza: Editorial Acribia, 1993. 681p.

GENIGEORGIS,C. Problems associated with perishable processed meats. Food Thechnology, v.40, n.4, p.140-154, 1986.

GERMANI, Y.; CUNIN, P.; TEDJOUKA, E. et al. Enterohaemorrhagic Escherichia coli in Ngoila (Cameroon) during an outbreak of bloody diarrhoea. Lancet, v.352, n.9128, p.625-626, 1998.

GIBBS, E.P.J. The public health risks associated with wild and feral swine. Revue Scientifique et Technique Office International des Epizootis, v.16, n.1, p.594-598, 1997.

GRUVER, K.S.; GUTHRIE, J.W. Parasites and selected diseases of collared peccaries (Tayassu tajacu) in the Trans-Pecos region of Texas. Journal of Wildlife Diseases, v.32, n.3, p.560-562, 1996.

GUERREIRO, M.G.; OLIVEIRA, S.J. de; SARAIVA, D.; WIEST, J.M.; KNECHT, F.L.; POESTER, F.P.; DIAS, J.C.A.; FERNANDES, J.C.T.; LANGELOH, A.; BAPTISTA, P.J.H.P. Bacteriologia especial com interesse em saúde animal e saúde pública. Porto Alegre: Sulina, 1984. 494p.

HAJDENWURCEL, J.R. Atlas de microbiologia de alimentos. São Paulo: Fonte Comunicações e Editora, 1998. 66p.

HAYES, P.R. Microbiologia e higiene de los alimentos. Zaragoza: Editorial Acribia, 1993. 369p. 
HOFER, E.; Zamora, M.R.N.; Lopes, A.E. et al. Sorovares de Salmonella em carne de eqüideos abatidos no nordeste do Brasil. Pesquisa Veterinária Brasileira, v.20, n.2, p.80-84, 2000.

HOFFMANN, F.L.; ROMANELLI, P.F. Análise microbiológica da carne de jacaré do Pantanal (Caiman crocodilus yacare). Ciência e Tecnologia de Alimentos, v.18, n.3, p.258-264, 1998.

JAY, J.M. Modern food microbiology. 5.ed. Maryland: Aspen Publishers, 1998. 661p.

JIMÉNEZ, E.G. El capibara: una fuente indígina de carne de la América Tropical. Revista Mundial de Zootecnia, v.21, p.24-30, 1977.

JOHNSTON, R.W. Salmonella in meat and poultry products. Dairy and Food Sanitation, v.3, n.11, p.415-417, 1983.

KANAI, Y.; HAYASHIDANI, H.; KANEKO, K.; OGAWA, M.; TAKAHASHI, T.; NAKAMURA, M. Occurrence of zoonotic bacteria in retail game meat in Japan with special reference to Erysipelothrix. Journal of Food Protection, v.60, n.3, p.328-331, 1997.

KYLE, R. New species for meat production. Journal of Agricultural Science, v.123, p.1-8, 1994.

LAVOIE, J.P.; LABBE, R.G.; CHINACHOTI, P. Growth of Staphylococcus aureus as related to NMR water mobility and water activity. Journal of Food Science, v. 62, n.4, p.861-866, 1997. 
LEAK, F.W.; LANE, T.J.; JOHNSON, D.D.; LAMBEY, J.W. Informe de investigacion: aumentando la utilidad de los despojos de los lagartos en Florida. Flórida: American Alligator Farmers Association, 1987. 15p.

LEITÃO, M.F.F. Microrganismos patogênicos na carne e derivados. Boletim do ITAL, v.59, p.15-48, 1978.

LORD, V.R.; FLORES, C.R. Brucella spp. from the capybara (Hydrochoerus hydrochaeris) in Venezuela: serologic studies and metabolic characterization of isolates. Journal of Wildlife Diseases, v.19, n.4, p.308-314, 1983.

LORD, V. R.; LORD, R.D. Brucella suis infections in collared peccaries (Tayassu tajacu) in Venezuela. Journal of Wildlife Diseases, v.27, n.3, p.477-481, 1991.

MADSEN, M. Prevalence of serovar distribution of Salmonella in fresh and frozen meat from captive Nile crocodiles (Crocodylus niloticus). International Journal of Food Microbiology, v.29, n.1, p.111-118, 1996.

MATYAS, Z. Papel dos veterinários na moderna higiene dos alimentos. Boletim Epidemiológico, v.11, n.5, p.81-86, 1979.

MELLO, L.E. Realidade do país muda análise de alimentos. Saúde em Debate, v.19, p.85-86, 1987.

MOLENDA, J.R. Escherichia coli (including O157:H7): an environmental health perspective. Dairy, Food and Environmental Sanitation, v.14, n.12, p.742-747, 1994. 
NARASIMHA, R.D. Salmonella in meat. Journal of Food Science Technology, v.20, n.4, p.156-160, 1983.

NOWAK, D.M.; PARADISO, J.L. Walker's mammals of the world. 2.ed. Baltimore: The John Hopkins University Press, 1983. 1185p.

OJASTI, J. Human exploration of capybara. In: ROBINSON, J.G.; REDFORD, K.H. (Ed.). Neotropical wildlife use and conservation. Chicago: University of Chicago Press, 1991. chap.17, p.236-252.

ONYANGO, C.A.; IZUMIMOTO, M.; KUTIMA, P.M. Comparison of some physical and chemical properties of select game meats. Meat Science, v.49, n.1, p.117-125, 1998.

PARDI, M.C.; SANTOS, I.F.; SOUZA, E.R.; PARDI, H.S. Ciência, higiene e tecnologia da carne. Goiânia: Editora UFG, 1993. v.1, p.585.

PAZAKOVA, J.; TUREK, P.; LACIAKOVA, A. The survival of Staphylococcus aureus during the fermentation and storage of yoghurt. Journal of Applied Microbiology, v.82, n.5, p.659-662, 1997.

PELAYO, J.S.; SARIDAKIS, H.O. Sorotipos de Salmonella isolados de produtos cárneos em Londrina - Paraná. Revista de Microbiologia, v.19, n.1, p.17-21, 1988.

PIÉRARD, D.; DAMME, L. VAN; MORIAU, L.; STEVENS, D.; LAUWERS, S. Virulence factors of verocytotoxin-producing Escherichia coli isolated from raw meats. Applied and Environmental Microbiology, v.63, n.11, p.4585-4587, 1997. 
RAY, B. Fundamental food microbiology. Boca Raton: CRC Press, 1996. $516 p$.

REDFORD, K.; ROBINSON, J.G. Empty forest. Bioscience, v.42, n.6, p.421-422, 1992.

REIS, R.B.; KRUGER, C.S.; MACIEL, M.S. Salmonella spp. em produtos cárneos comercializados no município de Cuiabá-MT. Avaliação da metodologia de pesquisa. Modelos de resistência a drogas antimicrobianas. Ciência e Tecnologia de Alimentos, v.15, n.1, p.7478, 1995.

RUMEU, M.T.; SUÁREZ, M.A.; MORALES, S.; ROTGER, R. Enterotoxin and cytotoxin production by Salmonella enteritidis strains isolated from gastroenteritis outbreaks. Journal of Applied Microbiology, v.82, n.1, p.19-31, 1997.

SALGADO, J.M.; GALVÃO, M.T.E.L.; STORER, M. DE L.P.; BRAZACA, S.G.C. Utilização de carne de capivara na elaboração de salsicha e fiambre. Boletim do Centro de Pesquisa e Processamento de Alimentos, v.17, n.1, p.83-92, 1999.

SANTOS, E.C. DOS; RODRIGUES, R.; TAVARES, W. DE A.; RIBEIRO, R.M.P. Ácidos graxos da gordura da capivara (Hidrochoerus hydrochaeris). Arquivo Brasileiro de Medicina Veterinária e Zootecnia, v.38, n.5, p.773-778, 1986.

SAS INSTITUTE. SAS: aplication's guide. Cary, 1996. 252p. 
SCOTT, T.; FOSTER, B.G. Salmonella spp. in free-ranging and farmed alligators (Alligator mississippiensis) from Texas and Louisiana, U.S.A. Aquaculture, v.156, n.1-2, p.179-181, 1997.

SHARF, J.M. Carne e produtos cárneos. In: Exame microbiológico de alimentos. São Paulo: Editora Polígono, 1972. p.145-156.

SILVA, L.F.W. Criação de capivaras em cativeiro. São Paulo: Nobel, 1986. 69p.

SILVA, N.; JUNQUEIRA, V.C.A.; SILVEIRA, N.F.A. Manual de métodos de análise microbiológica de alimentos. São Paulo: Livraria Varela, 1997. 295p.

SILVA NETO, P.B. Criação de animais alternativos em cativeiro: vantagens em relação às explorações tradicionais. In: SIMPÓSIO INTERFACE NUTRIÇÃO X AGRICULTURA, 2., Piracicaba, 1990. Anais. Piracicaba: FEALQ, 1990. p.167-173.

SILVA NETO, P.B. Criação racional de animais silvestres. Jornal do Fazendeiro, Goiânia, p.5, maio 1996.

SILVEIRA, R. da; THORBJARNARSON, J. B. Conservation implications of commercial hunting of black and spectaled caiman in the Mamirauá sustainable development reserv, Brazil. Biological Conservation, v.88, n.1, p.103-109, 1999.

SMITH, N.J.H. Utilization of game meat along Brazil's transamazon highway. Acta Amazonica, v.6, n.3, p.455-466, 1976. 
SOWLS, L.K. The peccaries. 1.ed. Arizona: The University of Arizona Press, 1984. 251p.

TOMPKIN, R.B. Botulism from meat and poultry products: a historical perspective. Food Technology, v.34, n.5, p.229, 1980.

TOMPKIN, R.B. Indicator organisms in meat and poultry products. Food Technology, v.37, n.6, p.101-110, 1983.

TRIGO, M.; RONCADA, M.J.; STEWIEN, G.T.M.; PEREIRA, I.M.T.B. Tabus alimentares na região Norte do Brasil. Revista de Saúde Pública, v.23, n.6, p.455-464, 1989.

TSEN, H.Y.; YU, G.K.; WANG, K.C.; WANG, S.J.; CHANG, M.Y.; LIN, L.Y. Comparison of the enterotoxigenic types, toxic shock syndrome toxin I (TSST-I) strains and antibiotic susceptibilities for enterotoxigenic Staphylococcus aureus strains isolated from food and clinical samples. Food Microbiology, v.15, n.1, p.33-41, 1998.

UNIPATH. Oxoid Salmonella rapid test: user's guide. Basingstoke, 1999.

VANDERZANT, C.; SPLITTSTOESSER, D.F. Staphylococcus aureus. In: Compendium of methods for the microbiological examination of foods. 3.ed. Washington: APHA, 1992. 1219p.

VICENTINI, A. Avestruz: uma ave muito interessante. Escala Rural, n.7, p.52-57, 2000. 